\title{
Resistance, Consensus, and Solidarity
}

García de Toledo, captain general of the Galleys of Naples, wrote a report to King Philip II that described the greatest difficulties he had faced throughout his years as leader of the squadron. In an attempt to give a Stoic tinge to his discourse, he associated every problem with one of the four elements in nature. The greatest obstacle was water, whose instability made all movement on the sea uncertain. Fire was a danger because ships were made of wood and cloth, while air imperilled any kind of maneuver - sometimes the wind did not blow at all; at other times it blew too hard. Finally, earth was represented by the rocks and sandbanks on which ships could run aground. The writer noted that at sea "you must defend yourself against many [dangers]," whereas on land there was only one: the crew members themselves, "who are looking you in the face day and night to seize the first occasion they can, and having performed their work all their lives, they well know how to act."

These reflections are valuable on several levels. They offer a glimpse into an officer's interior world and betray the psychological pressure, even for an captain general, of serving on the deck of a galley under the eyes of men hungry for any sign of weakness or opportunity. They reveal the ever-present threat of insubordination, mutiny, or flight, especially by rowers condemned to long sentences or slavery. An officer must fear his entire crew: "When you do not pay them it seems you cannot punish them, [and] everywhere you go they stir up trouble."1

These observations betray a significant aspect of the internal governance of a galley, and will form the basis for the final section of this book. We shall explore how the jurisdiction derived from ancient customs of the sea, and the ordinances we have described, were applied aboard the galleys themselves, and we shall draw some conclusions about cooperation and conflict among the various social, juridical, and religious groups who lived together within those small territories.

1 Fernández Duro, Historia de la Armada, 2:409. 
García de Toledo speaks of how an alert rower could take advantage of an officer's inattention when a ship was anchored close to land, and seems to be referring to the danger of escape. For Pantero Pantera this threat reflected poorly on the work of petty officers such as cómitres (rowers' boatswain) and alguaciles (sergeants-at-arms), who either failed to guard their rowers well-especially those serving life sentences, who were more likely to try to flee-or dealt out unjustified, arbitrary punishments. Sometimes discipline was applied unevenly, and there might also be personal quarrels or alliances between these officers and certain crewmen. Pantera claims that superiors might impose harsher punishments on some rowers than on others (in the form of beatings, confinement in chains, or hard labor) in order "to extract something from them," particularly money. He gives no specific examples, but we can imagine gambling debts, unpaid bills for purchases, and bribes offered in exchange for better treatment or for turning a blind eye to illicit economic activity.

Rowers sometimes escaped during brief absences from the ship to find water or firewood, but Pantera notes that the greatest peril came at night, when guards were careless or did not keep the lanterns alight along the rowers' benches. Most escapes were the result of such imprudence and were not violent, though there were exceptions - a few slaves from the Santa Lucía, who a few years later entered the papal galleys, had murdered the officer who was guarding them as they gathered wood in a remote spot. ${ }^{2}$ We will now consider how rowers could escape without being betrayed by their mates, how frequent those attempts were, and what legal consequences they brought.

\subsection{Escapees}

In his study of the Libro general de forzados (General book of convicts), Manuel Martínez shows that in the eighteenth century, 4 percent of convicts in the galleys tried to escape at one time or another. ${ }^{3}$ We have no similar registry for the early seventeenth century, but we can trace the phenomenon through bounties awarded by a galley's paymaster for "finds" (i.e., captures). The first period for which we have data is June 1602 to August 1603. In the first of those months, a slave named Alcácer escaped from the Santa Bárbara during a layover in Seville, Amete Zarzaña disappeared from the San Jacinto, and an unidentified

2 Pantera, Armata navale, 124-26.

3 Martínez Martínez, Forzados, 98. 
slave fled from the flagship, also in Seville. In 16o3, two escaped slaves from the San Jorge were recaptured. ${ }^{4}$ To these five slaves we should add the number of convicts, but the data are difficult to interpret. We know that two escaped in 1602 near Cartagena and that a third was retaken in 1603 after a brief flight, but from this point on the picture is less clear because the escapes listed were from prisons on land. In 1602, two men escaped from prison in Seville and another four from El Puerto de Santa María; in 1603, seven more escaped from the latter town. But we do not know if they were convicts condemned but not yet embarked, or men who had fled the galleys, been captured and imprisoned, and had escaped once more (a not unusual occurrence).

Unfortunately, we have no information for the second half of 1603 and all of 1604, so the series resumes in 1605. In early January, an escaped slave, who had probably fled the year before, was located in Cádiz, and in March bounties were paid for the seizure of two more. One slave was captured in Utrera in June, and two more escapees were retaken swiftly by several residents of El Puerto de Santa María in November. In the same year, one convict escaped in March and another in June, bringing the total for 1605 to eight rowers. The numbers fell slightly in 1606: two slaves were arrested in Jerez in April, and before the month was out another "disappeared" prisoner was found. A slave was taken in Rota in July, then in early autumn the skipper of a merchant ship trapped another, and several soldiers seized a convict, giving a total of six men for that year. Two escapes by slaves took place in 1607, a single individual from the vice-flagship in August and two men in the winter. For that year, flights by convicts were more common - seven bounties were paid to residents of Sanlúcar, Seville, Jerez, and Barcelona who caught them, so the annual total was ten men.

The records for 1608 contain fewer details, so we can confirm only that two slaves who had escaped from the flagship were arrested in Jerez and Medina Sidonia, respectively. There must have been some convicts as well, because elsewhere a payment of 3,00o reales is noted for their capture. Since the standard reward for capturing any escapee — slave or convict — was 100 reales, that sum suggests that a large group had fled; but the note also mentions "other things," so we cannot estimate the number of men involved. ${ }^{5}$ The year 1609 yields no data at all; there was more activity in 1610, but details become scarcer, and we learn only that five slaves escaped. A miscellaneous order records several payments (including one for renting a ship), but we do not know the

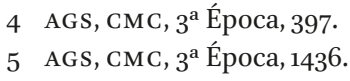


number of recovered slaves and convicts, or if any were among the escapees of that year. In 1611 the picture is slightly clearer, and we find seizures of six slaves and three convicts who had fled. ${ }^{6}$

There are no records for 1612-13, but sometime in 1614-15 a bounty was paid for four slaves from the San Martín recaptured after their escape. ${ }^{7}$ For the three-year period 1616-19, we learn only that in 1617 an escaped convict managed to reach Cáceres, where he was arrested but fled once more. His was not a unique case; in November of that year, two slaves seized in Ronda also managed to escape from jail. There are no more data for the remainder of the period, however. ${ }^{8}$

It is hard to determine whether the small number of escapes in these years reflects improved guarding of the crews or simple carelessness by the paymaster, who, as we know, was not always scrupulous about recording all the squadron's economic transactions. Therefore, it is best to focus on the years 1602 to 1608, which cover the final year of the more careful paymaster Juan Pascual and the first ones of his successor Juan Fernández de Villegas (before the latter was accused of fraud). During those six years of fairly complete records, we find forty-six excapes by rowers of the squadron, divided about evenly between twenty slaves and twenty-six convicts. These numbers might be slightly smaller if we knew that the two slaves who escaped in December 1607 were the same ones captured in Jerez and Medina Sidonia in 1608. But aside from this uncertainty, it appears that in the early seventeenth century an average of six or seven rowers managed to escape from the Galleys of Spain every year. Our data are too imperfect to allow a calculation of what percentage of all rowers they represented. Most often, the escapees seem to have been single men, at least once they reached land. The less common cases of pairs of fugitives might involve two slaves, two convicts, or one of each, as we see from the escapes from the vice-flagship in 1607 .

Another question is how successful these escapes were, measured either by distance or by time lapsed until capture. As to the first of these, the rower who covered the most ground was the convict who reached Cáceres in 1617; another, named Mexía, managed to return home to Almodóvar del Campo in 160o. ${ }^{9}$ Slaves obviously had a more difficult time, since most of them were caught somewhere near Seville or El Puerto de Santa María, but there were notable exceptions. Morisco slaves who managed to escape often went undetected

6 AGS, CMC, 3 a Época, 1570.

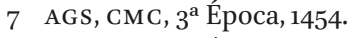

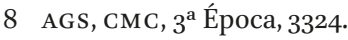

9 AGs, GyM, 572, 3 o1. 
"because, since they are Spanish-speaking, they handle the language easily."10 They were therefore more like convicts, who could forge the friendships needed to orchestrate their flight and then conceal themselves on land; they shared a cultural background with soldiers, sailors, and officers. Although slaves lacked that advantage, they still managed to escape successfully from time to time. Amete Zarzaña enjoyed his freedom for ten months, from June 1602 to March 1603, though we do not know where he escaped from or where he was caught. It seems that two unnamed slaves who fled in 1602 were not retaken for several years: in 16o9, after Pedro del Castillo, an assistant sergeant-at-arms in the galleys, had trapped them in one of his sweeps, two residents of the village of Orce in Granada were sentenced to pay their assessed sale price for having let them escape. The sentence might have come down some time after the events, but appeals to the Council of War usually did not take so long; those two slaves, perhaps Moriscos from Granada, might have been at large for a long time, which is surprising when we think of how few possessions escaped galley slaves must have taken with them.

In April 1598, Gian Andrea Doria authorized several soldiers to seek out two fugitives from the royal galley who had apparently been caught once and placed under a priest's supervision. But on arriving, they found that the priest, in an act of conscience, had let the men get away and that in their haste they had left all their goods behind. Doria suspected a less-than-pious motive, and asked his men to tell "the good priest" from him "that I believe that he let those men escape from there not out of charity but to steal their clothing. This makes me think that he is one of those priests who is not good, and if I cannot punish him because he is not under my jurisdiction I will at least report him to his bishop." This was not the only instance in which priests and monks were accused of sheltering runaways, though it may have been the most dramatic. What interests us here is that the belongings in question were no more than two shirts, three coats, three caps, and three pairs of trousers (the change of clothing that rowers were usually issued as winter approached). ${ }^{11}$ Once these fugitives had lost them, we can imagine how difficult their newfound freedom must have been.

We have to wonder whether many of these escapes were motivated by the causes that Pantera outlined in 1614. The records show that violence was not usually involved (at least, no instance of it appears for the Galleys of Spain), while there were many accusations against the men in charge of guarding the

\footnotetext{
10 Lomas Cortés, “Armada de Felipe III," 218.

11 ADP, scaffale 7o, busta 24: Gian Andrea Doria, 28 April 1598.
} 
rowers. ${ }^{12}$ Almost every escape was followed by punishment of those men, such as the sailor Francisco Rida and the soldiers Francisco Ferrer and Martín de Oviedo, accused of letting two slaves get away from the San Jorge in 16o3. Juan Velasco, a corporal of a galley, had to replace the slave Alcácer on the rower's bench after the latter's flight in $1602 .{ }^{13}$

The alguaciles were no more fortunate. One of their duties was to guard the most dangerous convicts and slaves, who were to be kept in chains and, as Gian Andrea Doria explains, to be visited "more than once a day, and be so well guarded by day and by night that not only are they unable to escape but cannot even speak to anyone, because they have plenty of allies." ${ }^{14}$ The prince, like Pantera, believed that the greatest risk of flight occurred at night and that to avoid it suspected men were to be always securely chained and kept from communicating freely with the rest of the crew. Therefore, if a rower escaped, the responsibility fell on the officer who had failed in his duty. ${ }^{15}$ That was the fate of the sergeant-at-arms of the galley Spinola who, accused of having allowed the convict Cristoforo Carcano to escape in May 1604, then vanished himself without a trace. For Gian Andrea Doria, there might be two reasons for his actions, "that he was in agreement with him [the convict], or for fear of being punished," although he was inclined toward the first; he knew from experience that in the galleys any crewman could be "favored and helped by others" as long as he was able to "spend."16

Doria's statement is significant. We have explained elsewhere how, by mixing convicts, slaves, and salaried rowers on the same bench, officers tried to prevent the formation of close friendships that might lead to disciplinary problems; that made it harder to develop any kind of collective feeling or esprit de corps. ${ }^{17}$ But this same information shows that rowers with resources, or those who could gain the friendship or connivance of an officer, could overcome that obstacle. Those relationships could turn dangerous, however. If collaboration with alguaciles was possible, so was collusion with other petty officers (in 16o9 Pedro García, a forger rowing in the Galleys of Portugal, was on the point of fleeing with the help of an Italian gunner $)^{18}$ and, above all,

\footnotetext{
12 Martínez Martínez, Forzados, 99.

13 AGS, CMC, 3 É Época, 397.

14 ADP, scaffale 85, busta 20: Gian Andrea Doria to the governor of Porto Ercole, 15 January 1601 .

15 Martínez Martínez, Forzados, 390-93.

16 ADP, scaffale 85, busta 29: Gian Andrea Doria to the Count of Fuentes, 5 May 1604.

17 Lomas Cortés, "Esclave captif," 23.

18 AGs, GyM, 726: “Don Luis Bravo de Acuña, cavallero ...," 13 June 1609.
} 
with fellow rowers. In 1618 Diego López, a convict in the Galleys of Denia, escaped from his bench. The auditor promptly blamed the alguacil and the three sailors who had been guarding the rowers on the night of his disappearance, but he extended the blame to several other rowers as well. Ruggiero Ferrero, Antonio Melone, and Andrés Gaspar, the convicts who had sat immediately in front of, behind, and beside López, were sentenced to two additional years in the galleys because in such a confined space they must have known of the planned escape. They were as guilty as the fugitive and should receive as heavy a punishment. ${ }^{19}$

This strategy was undoubtedly meant as an object lesson for the rest of the crew, and it sought to destroy any possible ties of comradeship and solidarity they might develop. Sometimes envy or friction with one's neighbors on the benches could frustrate a plan for escape. Francisco Dávalos was a Sicilian renegade who for a long time passed as a Turk in the unhappy galley San Jorge; when he finally gained permission to be ransomed in exchange for a captive from Algiers, he was betrayed and accused because it was rumored "among the Moriscos, convicts, and free men" aboard ship that he was a charlatan who only pretended to speak Turkish like a native. ${ }^{20}$ Still, cooperation among rowers was always present and at times was directed not to the flight of one or two rowers but to mutiny by a whole crew.

\section{$1.2 \quad$ Mutineers}

In May 1616 two Catalan galleys spied a North African galliot off the coast of Los Alfaques and set out in pursuit. But when they had almost overhauled her, most of the sailors and foremast hands of one galley, believing that the Moors would resist being boarded and would open fire, ran and hid under the rowing benches, getting in the way of the rowers and the soldiers who were preparing to board. In the confusion the sailors had stopped hauling on the sails, and the mainsail began flapping over the deck, hampering the soldiers even more; the rowers slackened their speed, until the prize pulled away and was lost. Because of the "little skill and valor [the men] had shown," the galleys' auditor brought a case against all those who had behaved "in a cowardly manner."21

Cowardice was one offense associated with insubordination aboard the squadrons; Marchena Giménez adds that a second one was failure to be paid. ${ }^{22}$ Since it was a serious charge, auditores would choose to bring a lawsuit rather

\footnotetext{
19 ADM, AH, 256, ramo 2-4.

$20 \quad$ Lomas Cortés and Benítez Sánchez-Blanco, "Seconde Inquisition."

21 AGs, GyM, 812: the Duke of Alburquerque to Philip III, 14 May 1616.

22 Marchena Giménez, "Vida y los hombres," 305-6.
} 
than leave it to the summary punishment that naval custom demanded. Above and beyond questions of ordinary discipline, the greatest danger aboard a galley was mutiny. The risk was easier to control in Christian squadrons, where slaves were kept in separate units and most of the rowers were convicts, but in Ottoman ones, where most of the benches were filled by captive Christians, ${ }^{23}$ the rowers formed a tighter and potentially more seditious collective. It would be wrong to assume that convicts were less dangerous because only a few were serving life sentences or because they suffered less than slaves. Although organizing a mutiny was more serious than attempting to desert, convicts did attempt it from time to time. In March 1599, Gian Andrea Doria resisted freeing a French rower, Honoré Vincens, even though the Peace of Vervins required it, because a few months earlier Vincens had tried to rouse the rowers of the flagship to mutiny. ${ }^{24}$

Though we have no details of that incident, we know it was related to an attempted mutiny aboard the galley Spinola in early August 1598. The disturbance began at nightfall while the ship was completing a short sail between the arsenal in Genoa and the quay at Pegi. A convict named Claudio, who was in charge of the tavern on board, was selling small amounts of cheese, bread, and pears to rowers who wanted to supplement their rations. It all seemed to start with a joke. During the trip, the stern rowers had proved more vigorous than those in the bow, so the convict Gio Spagnolo, the lead rower on the stern benches, decided to mock his mates who sat forward by throwing the bread he had just bought from Claudio, challenging them "to pick up the bread like [the] starving men" they were. The victims retorted that "the bow rowers had more bread and other things than those in the stern," and, before the alguacil could take control, a food fight broke out, Claudio's lean-to was overturned, and the confusion aroused the captain's suspicions, "especially when he saw the rowers happier than usual."

The next morning a soldier named Juan Domingo confirmed those fears. During the melee he had crouched next to a crossbow slit on the port side; he had noticed that while bread flew through the air, a Neapolitan convict named Grattapane, the galley's corullero (a favored rower of the sotacómitre, of the rowers' boatswain's assistant), ${ }^{25}$ had covered himself with a boatcloak and hidden himself. There, he was soon joined by Pietro Catalano, a convict who was a musician, who pretended that he needed to sleep. Domingo, suspecting that the two might be planning to escape, approached their hiding place to

\footnotetext{
23 Panzac, Marine, 34-37.

24 ADP, scaffale 85, busta 18: Gian Andrea Doria to the Duke of Guise, 20 March 1599.

25 Olesa Muñido, Galera en la navegación, 1:166.
} 
await developments. He did well, because at around two in the morning the two convicts began to converse. Catalano wanted to know why the "business" had not been done, and Grattapane replied that the captain had had all the weapons carried aft so that no one could get at them. Catalano complained that they might have attempted it in any case by seizing wood from the railings, and that it was a mistake to postpone the operation because they might be discovered. But Grattapane would not be moved: "Without arms nothing good could be done, and ... they had to await a better occasion." His companion finally agreed, after pointing out that they should change their signal: "He did not like to throw bread because it seemed too obvious." Like a good musician, he would have preferred a blast on a horn - then, if things went badly, they could throw it down on deck and in the confusion no one would know who was responsible.

Juan Domingo heard no more of the conversation, but he did not need to. The next morning he told the whole story to his captain and was soon seen leaving the ship in the direction of Doria's palace. The prince did not act at once, however. The reason is not clear, but perhaps he wished to give the tale-teller an alibi-the case should not seem to be brought immediately after Domingo had disembarked. On 13 August, the auditor began his questioning, which produced no ready answers. All the convicts whom Domingo had named denied taking part in the fracas, offering an impressive array of alibis. The Sicilian Marco Gionta, probably a benchmate of Grattapane's, said only that he "did not meddle in anyone else's business."

The auditor was not convinced. Juan Domingo, after returning from his interview with Prince Doria, had been assailed by questions from Grattapane and other convicts about his absence from the ship. The cómitre had apparently told Grattapane that he expected "a great dust-up with his Excellency," which put the whole group on the defensive. Catalano, when questioned, admitted having spoken with Grattapane that night, but only "about the queen's arrival" (the journey of Queen Marguerite was being planned) and whether she would be distributing any largesse. Grattapane confirmed the story and denied having pressured the soldier in any way. On 15 August, the auditor declared the interrogations complete and ordered all the accused to be strung up for an hour.

That public spectacle served as an object lesson to everyone on board; being strung up was one of the harshest punishments. A man would be hung by his hands (or other limbs) from the mainmast. The time he spent there varied, as did the severity of the torment. Sometimes he was left simply to bake in the sun, but he might also be hauled up and then dropped suddenly almost to the deck. It is easy to imagine the effect of this practice on the other rowers 
as they heard the cries and groans of their shipmates and saw how some tried desperately to resist, especially when they were hauled up for the second or third time. That was what happened to Claudio the taverner. Burned all over by the sun, he was cut down in a state of "delirium" to be bathed in water and vinegar. Another, seeing he was about to be hauled up again, pretended to be seized by a fit, but when the ship's barber said that he was only shamming, the punishment was repeated. When Gionta refused to confess, they tried hanging him "by three limbs," then recited a Credo before beginning a new round of haulings. Finally, after four or five days of torture, almost all the men began to confess-except Claudio, who held out. On 19 August, Gionta admitted that the night before the melee Catalano, who was being led unchained from one galley to another, had seized a chance to speak to Grattapane. It seems the latter had talked to the mate in charge of the forward hold, where most of the weapons were kept, and they had agreed that the next time the galley tied up at the quay in Pegi, the men would try to seize them.

To hide the attempt on the weapons, a diversion would have to be created. That would be the role of Claudio, the convict who ran the tavern, together with Spagnolo and another Neapolitan convict named Angelo. The stern oarsman would give the signal by throwing the bread he had bought from Claudio toward Angelo, who would be prepared to respond and encourage his fellow rowers to join in. Finally, Claudio would make sure that every possible projectile was within reach so that in the confusion the arms could be carried out of the bow. There, Grattapane and Catalano would be waiting to receive them and distribute them among the other conspirators, among them Gionta himself. Although the first part of the plan, the food fight, had gone well, they could not seize the weapons, which had unexpectedly been shifted to the stern hold. Later, Catalano was transferred to the royal galley and rumors about the betrayal began to circulate, so no mutiny was attempted again.

After this confession, all the dominoes began to fall. Grattapane finally admitted that before the trip to Pegi he had gone to the rail to relieve himself and had met Catalano there. As Catalano seemed distracted, he had asked what was on his mind, and the musician had replied "that he was thinking about his ill fortune, not able to earn a penny," and was wondering how he could regain his freedom. In this way, "discoursing about their enslavement, they [decided they] would try to raise a mutiny aboard the galley" and realized that they were at a good moment for it, as most of the soldiers were new recruits and, when the galley made its expected traverse from Genoa to Pegi, it would be only lightly guarded. They decided that the next morning they would speak with certain convicts about arousing the rowers, to convince them to take part and wield weapons if they managed to steal them. Catalano, in the trial, 
accused Grattapane of having been the only instigator and of having involved him only because they were rivals for the same woman. He claimed not even to have been aboard the Spinola that day-in fact, other interrogations tried to establish if he had been or not. After several days of torture, he admitted that he knew about the plan and would have participated, but he still refused to say any more or to betray any of his companions.

The squadron's auditor passed sentence at the beginning of October. Although the intent to mutiny had been proven, he believed he was faced with "a simple agreement with little basis and not well deliberated." He therefore condemned Spagnolo and Angelo to three additional years in the galleys, while giving life sentences to Grattapane, Catalano, Giova, and Claudio. He still thought that some of them-Grattapane, in particular-deserved to be hanged; in fact, he recommended to Gian Andrea Doria that he "make some kind of strong demonstration of it, by having one of them die as an example to the rest," in the presence of the whole squadron so as to awake "terror in them all." But he preferred that sentence to be handed down in the form of a special agreement, so as to preserve the respect owed to the captain general as head of the squadron's jurisdictional universe. ${ }^{26}$

This measure was normal in the governance of the galleys. Just as in any kingdom of the Hispanic Monarchy during the prolonged absence of the king, squadrons of galleys were used to the fact that their captains general were not aboard continuously, especially while the fleet was in its winter harbor. Therefore, serious problems were held over until the captain general could arrive, just as disputes were not presented to the king until he arrived in a city to convene Cortes. Gian Andrea Doria defined this practice perfectly when he commented on the report that contractors of the Galleys of Naples had sent him in 1587: "They were there continually desiring his very fortunate arrival to present their disputes, and to find relief for many offenses." 27 The practice arose from a wish for justice, which was the principle that the auditor upheld in 1598, that it must be clear who dispensed punishment and mercy in the squadron, and to whom its members owed fealty, devotion, and obedience.

This attempted mutiny in 1598 gives rise to other questions, first of all, about the characteristics of the conspirators. A cómitre favorite, a taverner, a musician, a mate with access to the hold-almost all of them belonged to the small subset of privileged rowers aboard the galley, the ones who through their service and talents had earned a higher status that removed them from

26 ADP, scaffale 70, busta 25, interno 2.

27 ADP, scaffale 70 , busta 25 , interno 5 . 
the benches and gave them a slightly easier life. Those convicts were the elite among the rowers, enjoying greater chances of success and influence over the others. Still, although they were better treated and even befriended by their superiors (the cómitre himself had alerted Grattapane that Doria was planning something), they still dreamed of escape and even attempted it. Given their standing among the crew, we may imagine how the other rowers felt when they saw their leaders hauled up on the mainmast and envisioned their own fate if they followed them. We do not know what ultimately happened to Grattapane and the other members of the plot. The trial records contain no reference to the interrogation and sentencing of the mate who would have opened the hold, or of others mentioned during the trial, one Mattuccio and a French convict called Honorato, who was certainly the Honoré Vincens who was not amnestied in 1599 because he had rebelled. Pietro Catalano might have had occasional contact with henchmen in other galleys, and perhaps the mutiny was meant to be wider (Vincens rowed in the flagship), but this is mere speculation.

The attempted mutiny of 1598 reminds us that for the period and the squadrons we are studying, there are no references to participation by slaves. The exception that proves the rule may be found in an appeal to the Council of War in October 1607, when its consultant reviewed a sentence by the auditor of the Galleys of Portugal. A renegade Muslim, Diego López, had converted to Catholicism and left North Africa to marry and settle in Lisbon. He had been denounced for receiving into his home "some Moors who had escaped from the galleys," for which the auditor had sentenced him to ten years as a rower, five absolutely and five more at the captain general's discretion. The Count of Elda had exempted him from the second period (another instance of how auditores respected and deferred to the jurisdictional authority of captains general). ${ }^{28}$ We do not know if López was deliberately concealing fugitives in his house or simply welcoming those who disembarked to conduct some business but intended to return. Without further data it is hard to classify the episode, but the auditor who sentenced him must have believed in his guilt, suggesting that former Morisco slaves were able to organize and count on some outside help. In the absence of more information, and to gain some notion of attempted mutinies by rowers of Muslim origin, we can turn to cases of Moriscos convicted to serve in the galleys.

The naval campaign of 1602 included Fray Mateo de Aguirre's plan to conquer Algiers ${ }^{29}$ and produced two episodes that reveal the presence of Moriscos

28 AGs, GyM, 677, fol. 624 .

29 Rodríguez Jouliá Saint-Cyr, Felipe III. 
on board. The viceroy of Majorca had commissioned a galliot from an armer with a corsair's patent; it was meant to serve for four months in the fleet that would attack Algiers. ${ }^{30}$ During several layovers between Cartagena and Cádiz, it was reinforced with all the petty officers and rowers it would need and was also boarded by Fray Mateo and two Muslim envoys, Mahamet Benamar and his son Ali. ${ }^{31}$ Those two passengers were meant to remain anonymous until the ship reached the North African coast, but that proved unrealistic in the confined space on board. The rowers soon learned of the plans against Algiers and reacted in two different ways. It seems that several convicts demanded payment for their silence, but others wanted to go much further and start a mutiny to keep the galley from reaching its destination; and one of the ringleaders, according to Mateo de Aguirre, was a Morisco. The attempt failed, however, and the Morisco and another convict were soon swinging from the yardarm. ${ }^{32}$

The second incident took place in Denia. The viceroy of Valencia stated that during that same galliot's layover there on $19 \mathrm{July}$, a soldier was seen to disembark and ask a Morisco for the shortest route to towns where New Christians (i.e., converted Muslims or Moriscos) lived. He did not get very far, however. We know that soldiers often aroused suspicion when they set foot on land, and he must have been under observation by the authorities, since they quickly detained him together with the Morisco he had questioned. The latter lost no time in confessing: the soldier had told him that he too was a Morisco, from Seville, and that the galliot was full of men on their way to conquer Algiers. He wanted to warn his fellows in Valencia that the king was preparing to "remove the Moriscos from this kingdom [of Valencia] to send them to the galleys, and that in Castile the Old Christians were enlisting in an army that would come to this kingdom to slit the throats of any New Christians who remained." The "Morisco" soldier denied it all, claiming to be the son of a Basque and a gunner in the Galleys of Spain. ${ }^{33}$ Unfortunately we do not know the end of the story, but these two accounts of conspiracies involving Moriscos in the royal squadrons suggest that they were trying to reveal the purpose of the mission to Algiers or even prevent it. The attempted mutiny in the galliot, and the case of the Morisco "gunner," might have been inspired by fear or some other scruple. The Count of Benavente seemed inclined to set the soldier free, which suggests that he did not take the report very seriously.

30 AGS, Estado, 19o: Fernando Zanoguera to Philip III, 19 May 16o2.

31 AGS, Estado, 191: 12 June 1602.

32 AGS, Estado, 19o: Fernando Zanoguera to Philip III, 2 August 16o2.

33 AGs, Estado, 19o: the Count of Benavente to Philip III, 3 August 16o2. 
We should not assume that convicts were invariably seditious or always trying to exploit weaknesses in their officers, as García de Toledo described them in his report to the king. We have already mentioned the conflict that arose in November 1606 when the governor of the castle in Lisbon tried to free two convicts from the galley Santiago who had been sentenced after having mutinied aboard a vessel in the fleet. At around noon, shouts were heard from the galley tied up at the pier, alerting soldiers who were playing cards on the pier nearby. Before the true cause was known, many people on shore thought that convicts aboard had started a mutiny. From a distance, it was clear that they had pulled down the awning over the deck and were waving their jackets raised on pieces of railing, shouting "Guards ahoy!" and "Come help the galleys!"

Although a few soldiers were on guard in the galley, many more of them were ashore (as the auditor was able to establish), and those were trying to find their way back. But when the first boats reached the galley and reinforcements arrived on deck, they found a strange situation aboard. It was true that some convicts were brandishing pikes, swords, and especially pieces of rail and that they had divided into groups. About twenty soldiers were confronting them with pikes and arquebuses, but they were not guards from the galley, and one convict kept saying, "Gentlemen, we must not rise up against the king!" It was finally understood that several of the viceroy's soldiers had tried to free their two comrades by force but had not removed their chains, so that as they tugged on them, they dragged other convicts along. The cómitre had tried to stop them by calling on the stern oarsmen from nearby benches to pull on the chain from the other end. Then, the viceroy's assaulters had injured the mate and an oarsman, provoking the convicts to hurl themselves on some of the soldiers, seize their pikes and swords, and form groups to defend themselves. What people on shore had seen and heard was the prisoners' call for help. In this case, they had armed themselves with wooden railings not to rebel but to protect and defend their shipmates and the whole galley. ${ }^{34}$

Although escapes from the galleys were common, it is significant that mutinies and rebellions aboard the squadrons were rare. One explanation might be the officers' efficiency in guarding the rowers and keeping them divided from each other, the relatively small number of slaves, and the dissuasive effect of public punishments, but other hypotheses are possible. Xavier Gil Puyol, considering the absence of revolts and revolutions in seventeenth-century Castile, suggests that confidence in royal justice and the stability of juridical culture in large swaths of Castilian society served to absorb many types of conflict and 
violence. He also notes the importance of mediation in resolving local disputes and confrontations, and the monarchy's ability to find consensus with local communities. ${ }^{35}$ Perhaps those same elements were present in galley squadrons, and the absence of serious mutinies responded to the same conditions as in other territories under the monarchy. In seeking answers, we can now examine how not only justice but also mercy and pardon were meted out aboard the galleys.

In October 1601, after the attempted surprise attack on Algiers ended in disaster, Gian Andrea Doria was stripped of his captaincy general of the sea. As soon as the news was known, most of the crew of the royal galley were seized by uncertainty. The prince had been the ship's almost exclusive patron, and with his departure the future of dozens of aspirants, favorites, sailors, salaried rowers, soldiers, and officers was left hanging - the royal galley would revert to an ordinary one and lose many of its men. Doria, eager to "pay all those who have served in my time," immediately began to negotiate with the court for the back salaries and stipends of the officers, aspirants, guards, and servants, while trying to extract a pledge to relocate them all to other squadrons. ${ }^{36} \mathrm{He}$ ordered his officers to reassure their men and promised them that, as long as the vessel stayed afloat, they would receive their due, even if it came from his own pocket. ${ }^{37}$

His negotiation did not bear fruit at first, but soon afterward a few officers such as Martín de Quijano began to receive grants in recompense for their services. ${ }^{38}$ Although many aspirants and favorites had been paid large salaries that perhaps could not be maintained, in June 1602 Doria extracted a pledge from the Duke of Lerma, through his agent at court, that all those who wished could transfer their assignments to the kingdom of Naples. ${ }^{39}$ As for the convicts, he asked for information on those who had completed their sentences or were about to do so, and offered a salary to any who wished to remain in his service as rowers (presumably in the Galleys of Genoa); the rest were transferred to

35 Gil Pujol, "Más sobre revueltas," 374-83, as part of a larger state of the question of rebellions in the seventeenth century.

36 ADP, scaffale 85, busta 22: Gian Andrea Doria to Martín de Quijano, 25 December 16o1.

37 ADP, scaffale 85, busta 23: Gian Andrea Doria to Pietro Serra, 5 January 1602.

38 ADP, scaffale 85, busta 23: Gian Andrea Doria to Martín de Quijano, 2 January 1602.

39 ADP, scaffale 85, busta 24: Francisco Tapia to Gian Andrea Doria, 2 June 1602. 
the Galleys of Portugal. ${ }^{40}$ It is surprising how many salaried rowers the prince had in the royal galley: 143 in 1600 and 1601 , according to a contemporary reckoning. Many were, in fact, convicts who had chosen to remain with him after serving their sentences in the preceding years, but there were also sailors and steersmen from many places of origin in Castile, France, and Italy; the prince also owned nineteen slaves who came from Fez, Tétouan, Chercell, Algiers, Bizerte, Djerba, Negroponte, and Istanbul. ${ }^{41} \mathrm{He}$ brought all of them with him, together with a few crewmen that the monarchy had no desire to transfer. Among them were the German guard of the captaincy general of the Sea, forty soldiers whom he offered to continue employing as his household and personal guards, in spite of the high cost of doing so. ${ }^{42} \mathrm{He}$ extended the same offer to two slaves, "the best of the royal ship," and two convict musicians-a trumpeter and a virtuoso called Catalano. ${ }^{43}$

The dearming of the royal galley shows the level of commitment that Gian Andrea Doria felt toward his men, from officers to rowers, and the extent of his patronage of them. Such bestowal of favors, and negotiation on the crew's behalf, was key to maintaining discipline as well as the bonds of reciprocity and consensus needed for good governance. Other officers under Doria served as his intermediaries, connecting him to the needs of his men and carrying out his policy of assistance.

\subsection{The Captain General's Mediation and Mercy}

We are now acquainted in general terms with the jurisdictional privileges that galley crews enjoyed when they went on land. These served as a public, external incentive for men to enlist and remain loyal, and were doubtless the most visible form of protection that captains general could offer their people. We have also seen how, in spite of strict rules of discipline, some escape valves were available to crewmen both aboard and ashore-permissiveness in the matter of gambling was one of the most obvious. Likewise, internally, there was a degree of support for rowers, particularly slaves, through their economic and commercial activity on board ship and the possibilities for ransom. We have noted several cases of slaves who either found enough money to ransom themselves or, in the opposite case of extreme poverty, wrote to their captains general seeking help and mediation in gaining their freedom.

\footnotetext{
40 ADP, scaffale 85, busta 23: Gian Andrea Doria to Martín de Quijano, 21 January 16o2.

41 AGS, Galeras, 78: "Buenaboyas de la Galera Real."

42 ADP, scaffale 85, busta 23: Gian Andrea Doria to Pietro Serra, 27 December 1601.

43 ADP, scaffale 82, busta 27: Domenico Sevo to Gian Andrea Doria, 13 July 1602.
} 
One of these petitions, penned by the convict Domenico de Vicenti and addressed to Carlo Doria in 1609, offers a glimpse into the phenomenon. Domenico suffered from two conditions common to many convicts. First, although he had finished serving his sentence, ${ }^{44}$ he had spent two months in a vain attempt to be freed; second, his poverty prevented him from bringing a formal suit. As a first step, he had "made a plea to his superiors for the freedom he was owed," but they had "replied that he should appeal to your Excellency." We see that galley officers themselves could advise the poorest rowers to seek justice through the captain general's favor, provide them with the means to do so, and convey their requests. De Vicenti not only made this plea but added a second one: "to let [him] be released without paying, since he has nothing to give as the usual 'glove money' to the officials." ${ }^{45}$ We remember how Gian Andrea Doria once observed that a rower could be helped if he was in a position to "spend"; obviously, it was hard to find support without funds for suborning the right people (paraguanti, or "glove money," being the Italian term for a bribe to a royal minister). Even in these cases, however, one could appeal to the captain general of the squadron over the heads of the officers who controlled the crews' everyday lives. Nicola Garibaldo's trial for smuggling began with an accusation that he abused his slaves, ${ }^{46}$ and in 1609 Pedro García, a forger whom we met above, caused severe trouble for the inspector of his squadron when he denounced him for robbery and other illegal actions. ${ }^{47}$

Rowers in possession of funds could use them for ends other than escape. In 1609 Lope de Sancho, Miguel Bellido, and Juan Albariel, Moriscos condemned to the galleys by the Inquisition, spent their money to buy one Muslim slave apiece to row in their stead (a fourth shipmate, Francisco Fernández, had tried to do the same). It seems that "because they were rich they wanted to buy them ... and they were good rowers," so neither the captain general of the Galleys of Catalonia nor the captain of the San Sebastián made any objection. The Moriscos had the freedom of the ship "with a single ring around one foot" while they served their sentences, a practice to which the Holy Office in Barcelona had objected. ${ }^{48}$ But rowers of any economic status had access to mechanisms for negotiating their complaints and demands, and at least some of them must have trusted in the value of petitions for mercy and justice. That did not entirely exclude other means of procuring their freedom. Pedro García first

\footnotetext{
44 Martínez Martínez, Forzados, 43-45.

45 AGS, Galeras, 215, fol. 291.

46 ADP, scaffale 70 , busta 25 , interno 17.

47 AGs, GyM, 726: "Don Luis Bravo de Acuña, cavallero ...," 13 June 1609.

48 AHN, Inquisición, libro 741, fols. 334-37.
} 
tried to escape but then offered his services to the king by revealing corruption among officers in his squadron.

Nor was he the only one to take that path, with greater or lesser success. In February 1602 a Morisco convict on the Santa Bárbara reported to the inspector Juan Ruiz de Arce that a fellow Morisco, Francisco Pacharo from Chelva, had confessed to him on his deathbed that a revolt was being planned in Valencia: that summer 80,000 men would recover 20,000 arquebuses they had stored in a cave in Chiva, and would start a war. Ruiz de Arce did not give much credit to the tale, but the convict had supplied a list of conspirators that needed investigation; ${ }^{49}$ therefore, the accuser was taken from his galley and sent to Valencia, where Archbishop Juan de Ribera was waiting to interrogate him. ${ }^{50}$

Anselmo Dondano, a convict from Savoy who rowed in the Galleys of Genoa, was less fortunate. In March 1604 he confided to his officers that he had found certain papers, which seemed to contain plans for an attack on Genoa by the Duke of Guise. Since Gian Andrea Doria was absent, the captain of the galley alerted Doria's administrator, Pietro Riccardo, who acted as discreetly as his master had done on hearing of the intended mutiny in the Spinola in 1598. At midnight, four of the prince's German guards seized Dondano (we see that they were still in Doria's employ two years after the royal galley had been dearmed). To disguise the motive, they took three other convicts as well, and once in the palace they confined each one separately, keeping them awake all night so that Dondano would not be the only one to show signs of interrogation. But the ruse was soon revealed: the prisoner claimed not to know whom the papers belonged to, only that "they had been thrown under his bench." When Gian Andrea Doria learned of the episode, he called the prisoner "a madman or a rogue," concluding that he had written the papers himself; as he later explained to the governor of Milan, Dondano had offered a "service" to the republic that he might later use to request his freedom..$^{51}$ It seems that it at least released him from the rowers' bench, because he spent two months in prison before Doria handed him over to the republic, after telling him in person "that if they give him any more [papers] he should report it at once, so we can see who gives them to him.."52

Prince Doria did not attend to accusations by his convicts only in especially serious cases like this one. As he explained in a letter to the Prince of Avellino

49 AGS, Estado, 189: Juan Ruiz de Arce to the Duke of Medina Sidonia, 21 February 1602.

$5^{\circ}$ Ags, Estado, 192: the Count of Niebla to Philip III, 13 August 16o3. See Catalá Sanz and Urzainqui Sánchez, Conjura morisca, 11-42.

51 ADP, scaffale 82, busta 30: Pietro Riccardo to Gian Andrea Doria, 29 March 1604.

52 ADP, scaffale 85, busta 29: Gian Andrea Doria to the Count of Fuentes, 27 May 1604. 
in January 1601, he did not normally intervene when a case first arose aboard his galleys but allowed the auditor of each squadron to proceed as the law required. If the parties did not agree, however, the case would be passed up to the auditor general of the fleet, based with him in Genoa. At that point, by his authority as captain general of the sea, he would review the appeals of cases from all the squadrons. ${ }^{53}$ That was the occasion on which the prince might be consulted and informed about requests by his rowers (for ransom, freedom, and so forth) and could use his position as an arbiter to confirm a sentence or grant clemency.

The episode of a convict named Giuseppe Questa will illustrate how Doria might review sentences passed by auditores. In 1598 Questa wrote to Doria about his history: A few years earlier, after an attempted escape, he had been forced to pay back a sum of money that the prince himself had given him "as an act of mercy." But since the failed escape had earned him a longer sentence, he was asking the prince at least to return his money, to ease his living conditions a little. ${ }^{54}$ What makes the case even more interesting is that at the same time, in a coordinated effort, his brother Lorenzo Questa wrote to the prince asking for his own freedom. He adduced the fourteen years that his brother had served of his sentence, and the fact that his aged mother and his daughter lived in extreme poverty with no means of support. He threw himself on the mercy of the prince, who considered the case but did not grant the request, because there had been no official shortening of the sentence. ${ }^{55}$

Unfortunately, we do not know if Questa regained his confiscated funds, but we can see how with a family member's help he managed to appeal to the prince by two different channels. That suggests that some convicts had at least rudimentary legal knowledge and drew on it in trying to solve their problems peacefully - without abandoning more radical solutions altogether. We have a few examples (though too few to be called a trend) of the sequence "attempt to escape/appeal to the captain general." Perhaps rowers, after serving many years of their sentences, learned to adapt to certain legal forms, with some help and guidance from officers who wanted to minimize escapes and maintain order. That would encourage good habits of mediation in the face of conflict, interpersonal violence, or injustice, in much the same way that officers trained prisoners from the beginning to adapt to the harsh conditions of their service.

We must consider how often these appeals were successful. We have already noted how, faced with a chronic shortage of rowers, officers often forced

\footnotetext{
53 ADP, scaffale 85, busta 20: Gian Andrea Doria to the prince of Avellino, 16 January 1601.

54 ADP, scaffale 70, busta 24: "Giusepe Questa, figlio di Gio Batista. ..."

55 ADP, scaffale 70, busta 24: "Ricorre a V.E. il padre Lorenzo Questa...."
} 
convicts to remain at their benches even after having completed their sentences. ${ }^{56}$ But we have paid less attention to cases in which prisoners obtained their freedom before their time was up. We refer here not to exceptions such as ransoms, invalidism, or exchanges for slaves but rather to instances in which a prisoner was freed through the intervention of a tribunal or a private individual.

First we must identify the various tribunals that sentenced convicts to a particular squadron. The Galleys of Genoa, for example, received most of their convicts from the Senate of Milan, but also from different vicaries and the barons of Lombardy, the Lords of Genoa, the Duke of Parma, the Duke of Mantua, the magistrate (grasciero) of Piombino, the Lords of Lucca, and in lesser measure the Vicaria of Naples. ${ }^{57}$ Prince Doria therefore had to consider petitions for clemency from these tribunals, because to deny them could complicate the future flow of convicts into the squadron.

To assess how often Prince Doria received appeals from these entities we can take the year 1600 as representative. In January, the Marquis of Cusano, a Milanese aristocrat, informed Doria that he had decided to pardon a convict known as "Il Balabene" who had been sentenced to the galleys a few years earlier. ${ }^{58}$ In March, Cardinal Madruzzo wrote to him from Rome requesting freedom for Vincenzo, a convict from the flagship, who had served only three years of a ten-year sentence for homicide. ${ }^{59}$ In April, the confaloniere of Lucca asked him to free Giovanni di Antonio because the man had almost completed his sentence, ${ }^{60}$ and in August the Duke of Parma reported that after receiving many appeals to free Anibal Baretta, he had decided to do so and hoped that Doria would expedite the matter. ${ }^{61}$

The most frequent and insistent petitions came from the governor of Milan. In January, he requested freedom for Bartolomé Vergara, a convict in the royal galley, because he had been rowing for many years. ${ }^{62} \mathrm{~A}$ new petition arrived in May, motivated by a conflict with the vicar of the bishop of Tortona: the governor had sent one Alejandro de Inicia to the galleys before the vicar could confirm the order, and to avoid problems he wanted to have him back again. ${ }^{63}$ In June, at the request of the Senate of Milan, he interceded on behalf of Mario

\footnotetext{
$5^{6}$ Heras Santos, Justicia penal, 315-16.

57 ADP, scaffale 70 , busta 25 , interno 12.

$5^{8}$ ADP, scaffale 82, busta 23: Marquis of Cusano to Gian Andrea Doria, 15 January 1600.

59 ADP, scaffale 82, busta 23: Cardinal Madruzzo to Gian Andrea Doria, 25 March 1600.

6o ADP, scaffale 82, busta 23: the confaloniere of Lucca to Gian Andrea Doria, 17 April 1600.

61 ADP, scaffale 82, busta 24: Ranuccio Farnese to Gian Andrea Doria, 5 August 16 oo.

62 ADP, scaffale 82, busta 25: the Constable of Castile to Gian Andrea Doria, 22 January 1600.

63 ADP, scaffale 82, busta 25: the Constable of Castile to Gian Andrea Doria, 10 May 1600.
} 
Guatordio, ${ }^{64}$ and in August did the same for Gio Maria Savo. Savo had served only five years of his ten-year sentence, but when the governor had visited Genoa someone (apparently, "a person who could not be denied") had "sought him out urgently," and therefore after a positive vote by the treasury and the Senate, "I have resolved to show him mercy, with the condition that he serve the rest of his time in Flanders in the armies of His Majesty at his own expense, and secure his pledge with the sum of three thousand scudi to accomplish it."65 Finally, in December, he requested "grace and mercy" for Juan Serrano Aguilera, a fourteen-year-old who had been sentenced for homicide. ${ }^{66}$

Gian Andrea Doria granted all nine petitions, but not without complaining to the governor about the number of his requests and especially for having offered him an "equivalent recompense" in the form of new convicts, "which will not be a poor one and will not be long delayed, since we have a large catch" of highway robbers. A prisoner could be exchanged for a slave, but not one prisoner for another. ${ }^{67} \mathrm{He}$ sent a similar complaint to the confaloniere of Lucca, claiming that the convicts arriving from that jurisdiction were beginning to be "not very useful, because of the many clemencies that are offered to those serving long sentences." But Lucca was not listening and almost immediately sent two more notices, requesting freedom for Vincenzo del Mancino ${ }^{68}$ and Gaspar Beretta. ${ }^{69}$

As the confaloniere admitted in a later missive, all those pardons resulted not from close consideration of each case but from the sheer volume of appeals for clemency on behalf of convicts. ${ }^{70}$ One such plea was made by the wife of the convict Miguel Morata, a former bandit. In 1607 she spent eight months in Madrid until finally Antonio Aróztegui, secretary to the Council of War, sent a formal notice to the captain general of the Galleys of Portugal asking if her husband could be freed. The wife even obtained a grant of 50 reales from the council to pay for her return home, because she had been through so much "trouble" during that period. ${ }^{71}$

64 ADP, scaffale 82, busta 25: the Constable of Castile to Gian Andrea Doria, 17 June 1600.

65 ADP, scaffale 82, busta 25: the Constable of Castile to Gian Andrea Doria, 4 August 1600.

66 ADP, scaffale 82, busta 25: the Constable of Castile to Gian Andrea Doria, 15 December 1600 .

67 ADP, scaffale 82, busta 25: the Constable of Castile to Gian Andrea Doria, 10 May 1600.

68 ADP, scaffale 85, busta 20: Gian Andrea Doria to the confaloniere of Lucca, 16 February 1601.

69 ADP, scaffale 85, busta 20: Gian Andrea Doria to the confaloniere of Lucca, 18 February 1601.

70 ADP, scaffale 82, busta 30: the confaloniere of Lucca to Gian Andrea Doria, 5 January 1604.

71 AGs, GyM, 677 , fol. 57 . 
An additional resource was the Council of War and the various territorial councils, which also acted as ultimate courts of appeal. In July 1619 alone, the following petitions passed through the hands of the council's secretary: Ana Hernández, mother of the convict Juan de Figueroa, asked that his sentence be reduced from life to a limited time; he had been rowing for eight years, since the age of thirteen. Juan Cabrera, a convict in the San Jorge, had served six years of his eight-year sentence and claimed to be "broken and useless." Nicolás Gentil, a pilot and skilled mariner in the same galley, had been sentenced to three years without position or salary after his ship was lost. Juan Caballero, inspector of the Galleys of Portugal, had been condemned by his captain general to lose his rations and stipend. Captain Domingo de Acosta demanded that the auditor of the Galleys of Spain recuse himself from a certain investigation. Antonio Cabia, a reserve cómitre in the galley San Francisco, demanded his back pay. Sebastián Rico, cómitre of the Spanish flagship, had been shot in the arm during a skirmish with a Turkish ship and requested extra funds to support his household. Francisco Maza, captain of the San Juan Bautista, sought promotion to sergeant major of the Galleys of Spain. Melchor de Torres, "officer of the court of the auditor general of the galleys and the fleet," demanded the salary owed him for having served temporarily as a prosecutor. The paymaster Fernández de Villegas had a long-running dispute with the Junta de Galeras, which oversaw the Galleys of Spain, for his management of their budget. Juan de Falces, of the Galleys of Sicily, and Francisco de Vargas both requested a supplement to their pay. Cristóbal Fontanet, a soldier in the Galleys of Catalonia, wanted a promotion to lieutenant. Juan Gómez, a soldier in the Portuguese vice-flagship, sought an increase in the supplement he already had. Two gypsies, Sebastián García and Sebastián Hernández, had been sentenced to row for three years for stealing a pig; they claimed to have been beaten for no reason, and asked to be freed. Juan Griego, captured from an Algerian galliot, thought that he should be released for being a good Christian. The father of the former chaplain of the Galleys of Portugal hoped to collect the back salary of his deceased son in order to pay a granddaughter's dowry. Miguel González, a slave already mentioned, also petitioned. Francisco Antonio de León, a convict in the royal galley, asked to be freed after sixteen years of rowing; his shipmates Claudio de Baudio, Juanelo de Lofredo, and Juan Caballero made the same request. Antonio Lauro, a convict in the Galleys of Genoa, claimed he had been wrongly registered in the squadron's books as a slave. And finally another gypsy, Francisco Palomero, convicted to a life sentence, demanded his freedom after thirty-two years at the oar. ${ }^{72}$ 
In the space of only a few weeks the secretariat of the Council of War received twenty-five petitions from crew members of every squadron of the monarchy, from convicts requesting their freedom to naval and military officers appealing their sentences or seeking royal favor toward a promotion, a raise in salary, or other forms of patronage. To these we must add the pleas for clemency that some convicts sent to religious institutions. In April 160o, the Dominicans of the Predicadores convent in Valencia interceded for Juan Terán, convicted to the galleys without pay for having stabbed a man. ${ }^{73}$ And in February 1602 the confraternity of Santiago el Menor in Piacenza convinced the Duke of Parma to free Antonio Francesco Riva from the Galleys of Portugal. ${ }^{74}$ Other petitions were addressed to the ecclesiastical tribunals that had issued the sentences and even to the Pope. ${ }^{75}$

In short, it is clear that in the galleys of the Hispanic Monarchy a widespread juridical culture drew on every possible avenue for justice and clemency. Petitions were forwarded continually at every level, from each auditor court up to the Council of War. And though it might appear that pardons from the latter institution were not easy to obtain-since it was always conscious of needing to keep the rowing benches staffed with experienced men-there was better luck in the territorial, seigneurial, and ecclesiastical tribunals, where the principle of maintaining the squadrons' interests was attenuated or even absent.

Captains general had the option of opposing these pardons, even by seeking the king's backing. The Duke of Tursi attempted it twice in 1620, first when the Senate of Milan requested freedom for the forger Juan Domenico Scio, ${ }^{76}$ and again when the Council of Italy asked him to pardon a pimp, Juan Bautista Gabrietti. ${ }^{77}$ Both petitions were denied. When central councils of the monarchy ruled against captains general in favor of prisoners, crewmen must have felt renewed faith in royal justice. That fact, together with their captains general's patronage, offered petitioners a broad range of possibilities for channeling their demands and resolving their conflicts, in ways that were legal and guaranteed. It is fair to conclude that the absence of mutinies in the galleys of the Hispanic Monarchy during these years might obey the same motives that avoided rebellions in other territories. To better

73 AGS, GyM, 571, 185 .

74 ADP, scaffale 82, busta 27: Ranuccio Farnese to Gian Andrea Doria, 19 February 16o2.

75 AGs, Galeras, 230, fol. 346.

76 AGs, Galeras, 23o, fol. 364 .

77 AGs, Galeras, 8, fol. 5 . 
understand how peace was maintained in the galleys, we must analyze the role of officialdom in building consensus.

\subsection{Auditores, Inspectors, and Other Officials}

It is not easy to study the daily administration of justice aboard the galleys. Reasons include the summary nature of judgments and the paucity of documentation, which preserves only the most serious cases that carried more weight in the judicial process. We are not certain, therefore, of the extent to which auditores' courts were able to manage tensions among the crew. We can examine recorded deposits of penas de cámara, fines imposed for especially serious offenses, but just as we have seen with account ledgers, many paymasters were unsystematic in noting down these types of payments. During the period under study, in fact, we have full accounts only for the three years from November 1616 to October 1619 .

In addition, the data are sketchy. The largest fine during this time $(1,309$ reales) was imposed in December 1616 by the Marquis of Santa Cruz on two soldiers, Pedro de Silva of the flagship and Pedro de Rojas of the San Martín, for an unreported crime. The next notation, in January 1617, records a death sentence decreed by Emmanuel Filibert of Savoy against Pedro Antolín, a soldier of the royal galley. In July of that year Álvaro Martín, a soldier in the Toledana, was made to pay 24 reales to the tribunal for an unnamed offense. In June 1618 , Santa Cruz sentenced two soldiers to pay 55 reales. Manuel Alberto, skipper of the San Jorge, was fined 200 reales in October, presumably because of the "loss" of his galley mentioned above. And in November four crewmen of the royal galley - the captain Gregorio Buriel, the corporal Juan Leonés, and the soldiers Mateo de Torres and Antonio de Silita - were sentenced to pay 700 reales. The year 1619 brought two sentences. The alguacil of the San Juan, Pedro Cifuentes, was fined 294 reales, and a convict from the San Pedro named Juan, whom a court in Vélez-Málaga had sentenced to pay 176 reales before he was taken on board, was cited because he still owed that sum. ${ }^{78}$

We find, then, that in the space of three years the court of the Galleys of Spain imposed only eight fines, for a total of 2,90o reales. The auditor may have handed down more sentences, because we know that in 1619 the pilot of the San Jorge appealed his sentence of three years without position or salary (presumably, for the loss of the ship, the same offense for which his captain was fined). Further, the accounts record only payments actually made, so that more people might have been assessed fines but have simply been unable to pay.

78 AGs, CMC, 3 Época, 3324. 
Still, we can form some hypotheses. It is notable that only skippers and soldiers were fined (the exception, for the convict in the San Pedro, was imposed at the request of a different tribunal). That fact, and the amounts involved, suggest that at least two fines represented the assessed price of one or more escaped rowers, while others corresponded to graver offenses like murder or damage to royal property. It is also possible that some fines included fees to scribes who penned documents in the appeals. But even then, and assuming there might be other unpaid amounts, this three-year sample suggests that the auditor of this squadron only occasionally levied fines on crew members. Again, we find a tendency toward summary justice, expressed especially through an immediate economic penalty. ${ }^{79}$ But we cannot rule out the possibility that captains general, who, after all, could appoint and dismiss auditores, might have a policy of assisting the accused, benefiting some soldiers and sailors, whose pay was usually scant and often delayed.

The most significant aid that auditores could offer the crews, however, even beyond the protection they provided against other jurisdictions, was their testamentary function. As Alessandro Farnese explains in his ordinances of 1587, one of the chief duties of the office was to administer the estates of deceased soldiers. By hearing eyewitness statements from a soldier's shipmates and chaplains, the auditor tried to determine the man's last wishes to the extent possible; he also had to inventory his possessions and preserve them until his heirs could claim them, after settling any legitimate debts the man had left behind, if his funds were sufficient. ${ }^{80}$

The Junta de Galeras accepted these same rules for the monarchy's squadrons and applied them to all Christian crewmen. Chapter 12 of the conditions for contracting galleys, drawn up in 16o1, called for preserving for three years not only the goods a man possessed at his death but also his back pay, while a search was conducted for his heirs. Only if none were found by the end of the period could his possessions be sold at auction, with the stipulation that profits be devoted to ransoming captives. ${ }^{81}$ We unfortunately have little information about this practice. Unlike the possessions of slaves, which were usually looted by their ships' officers and rarely auctioned by the paymaster (as we saw in the last chapter), the goods of other rowers, sailors, and soldiers were kept in the custody of the auditor or his designated official, and we have been unable to locate the relevant testaments.

\footnotetext{
79 Martínez Martínez, Forzados, 91.

8 o Casado Moreno, "Ordenanzas," 449.

81 AGs, GyM, 579, fol. 491.
} 
One will that has survived was dictated by the convict Lelio Merenda aboard the galley Duquesa, belonging to the Duke of Tursi, which was quarantined in Palermo's arsenal in April 1624 during an outbreak of plague. The dying prisoner, in the presence of his cómitre, the chaplain of the flagship, and one Francisco Brochero, named as his sole heirs Ginés de Torres and his son Pedrocuriously, omitting his wife. He expired "fairly quickly, without having made any other will." Because of the plague in the city, no notary could be found to certify his death, so that later the three witnesses had to retell their story before the auditor Antonio Gabriel, pretoris of the squadron.

We know of this case thanks to the suspicions of the auditor, who initiated a trial in the belief that Lelio had actually not died but escaped and that the witnesses were giving false testimony. ${ }^{82}$ It offers us a glimpse into how wills were recorded in the galleys, and how cautious auditores were in accepting the deceased's last wishes as genuine. Recording them correctly was supposed to involve the royal scribe from the auditor court. The case of Juan Hurtado, captain of a galley in the squadron of Spain, gave rise to a conflict. When he wished to make his will, he feared that "the deposition was invalid because the scribe was not a public and official one," so he consulted a second scribe in El Puerto de Santa María before his death in 1616. When Hurtado's executors tried to have the second will read, the auditor refused, because "the testator was captain of a galley and the affairs of a galley's people fall under the jurisdiction of the auditor, and as such must be handled by his scribe because they belong to his tribunal and none other"- that was the precedent in other cases. The local corregidor, however, protested that "when the galleys are in this port or in any other where there are public, official scribes, by the laws of the kingdom any wills and contracts made with them by people from the galleys must be considered valid." The galley's scribe "can attest only to the judicial acts that pass before the auditor in the course of his trials," with recognized exceptions: "When ... they are at sea, or on some deserted shore, or on the Barbary Coast or in other places where there can be no public scribes." Besides, although Hurtado was a member of the squadron, "on his death he lost the privilege of military law that he had enjoyed." There were apparent precedents, moreover-the cases of the inspector general Alonso de Velasco, who dictated his will in El Puerto, and the purveyor Felipe de Porres, who died intestate and whose inheritance was recorded by a scribe from the same town. 
Although the auditor defended himself with a report we will examine below, in the end the Marquis of Santa Cruz decided to close the matter and defer to the corregidor of El Puerto this time, because the situation had become less clear. It began to be known that several years before, the auditor had ordered Captain Juan Ruiz to be violently seized. (He had learned that the captain had dictated his will before a public scribe, and had threatened to demote him to rower if he did not revoke it.) ${ }^{83}$ This new dispute with the corregidores of El Puerto shows us another dimension of the jurisdictional conflicts that arose as the authority of auditores was still being constructed and its relationship to land-based justice worked out. Auditores obviously set great store by their areas of authority; they were one of the special privileges that attracted men to serve in the galleys, and promised some kind of positive and noncoercive relationship between the auditor and members of the crew. In the judge's care for the estates of deceased rowers, he and other officers presented themselves to the men as guarantors not only of their basic rights but also of their possessions and last wishes, while those convicts, sailors, and soldiers faced multiple difficulties and had no public scribes to assist them.

We find an enlightening example in a letter that the Duke of Tursi wrote to the inspector Martín de Quijano in April 1603. Shortly before, on his deathbed, Captain Pedro de Eguera had entrusted Quijano with his whole worldly estate $(3,000$ reales) and made him promise to manage it until his nephew and heir reached adulthood. Quijano had done so for a while, but Tursi, after asking his father, Prince Doria, for permission, had assigned his two administrators in Genoa, Francesco Roberto and Pietro Serra, to take over; that freed the inspector from the task of investing the money until the child was old enough to receive it. ${ }^{84}$ The incident illustrates the many-layered nature of this policy of assisting the men-even at the captain general's level there was concern for protecting men who had served in one's squadron. And Roberto and Serra were not just any agents, but the principal managers of the Dorias' fortune. In the face of such favor, officers would feel renewed trust in their captain general protection, thus strengthening the bonds of reciprocity and mutual interest between them, bonds essential to creating the consensus required to govern the "Babylon" that was a squadron of galleys.

Officers of the galleys, freed from responsibilities of this type, could extend some help in turn to other members of the crew. Quijano, the inspector, was

83 Ags, GyM, 858: "Relación del corregidor del Puerto de Santa María."

84 AGs, Galeras, 6 , fols. $487-88$. 
solicitous for maintaining good relations with his captains. In 16o3, when Captain Juan de Verio left the squadron as his company was being reorganized in Milan, Quijano asked him to recover some gold buttons, valued at 500 reales, that he had pawned (we do not know if aboard his own ships or in a coastal town). ${ }^{85}$ It seems he also helped Captain Ponz, who did not want some soldiers of his company to be taken off the rolls (some were ill in Savona, while others had gone to "confess" in Alessandria), and he sometimes mixed the captain's letters with the squadron's official correspondence so that they would arrive more quickly. ${ }^{86}$

Captains, relieved of some duties by financial officers, could concentrate on maintaining cohesion among their soldiers, as when two of Captain Ponz's men were accused. The scandal broke out aboard his galley in March 16o3. It seems that a buenaboya named Dominguillo had given two of Ponz's soldiers, Pedro del Castillo and Juan García, 6 libras of smuggled gunpowder to be sold in Elba and Piombino, but the plan had been discovered. The squadron's officers assumed that the men had made other such attempts before, counting on the silence of their shipmates, so they accused they entire crew. The lack of privacy aboard weakened the crew's protests, but Ponz hastened to take their part. He claimed that they slept far from the hold where the powder was stored, and could not have collaborated if the man who guarded the powder had done his job. With this explanation, Ponz appealed to Quijano for help, while making him a significant offer-all the soldiers in the company offered to repay the price of the stolen powder out of their own pockets, so that their companions would not be consigned to the rowers' benches as punishment. ${ }^{87}$

\subsection{Solidarity among Soldiers, Sailors, and Rowers}

Solidarity among shipmates was the norm. When in 1619 Pedro Beltrán, alguacil aboard the galley San Francisco, was put in irons after two slaves had escaped, he asked Melchor de Borja, captain general of the Galleys of Denia, to let his friends take up a collection to support his appeal to the king. He presented a robust list of the names of his shipmates and the amounts they had pledged. In his own galley eighteen soldiers, fourteen buenaboyas, seven sailors, the drummer, the steersman, and the chaplain offered whatever they could, for a total of 733 reales. But contributions came from other ships in the squadron as well. Thirty soldiers from the flagship gave 423 reales, and five men of the vice-flagship also reached into their pockets. Only two sailors from the

85 AGs, Galeras, 6, fols. 478-79.

86 AGs, Galeras, 6, fols. 464-65.

87 AGs, Galeras, 6, fols. $472-73$. 
Santo Domingo took part, but even so, the end result was significant. Thirty-five men from Beltrán's own galley added to the pot, with contributions ranging from 4 reales from each buenaboya to 38 reales from the drummer Juan Bautista. From other ships in the squadron, a total of thirty-seven men, especially soldiers, joined the effort, paying 20 reales apiece. In all, Pedro Beltrán's "friends" in the squadron provided him with 1,56 o reales. ${ }^{88}$

This type of collection was common during musters, with the funds devoted most often to care of the sick and injured in the squadron's hospitals. Although patients were most often cared for in a hulk, ${ }^{89}$ it was not unusual to rent houses on land for the purpose. In El Puerto de Santa María, for example, the Galleys of Spain paid a token annual rent for houses ceded by the monastery of Santa María de la Victoria. They kept a small staff there, the first physician of the squadron, the hospital's steward, and the senior monk, who received and administered the modest amounts that were assigned. The ledgers for 1603 show that the monk recorded sixteen payments for a total of 3,840 reales, a trivial sum in relation to the squadron's annual budget, and in comparison to other military units. ${ }^{90}$ Except for small amounts for maintaining the building (the ceiling was repaired in 1603), most of the money went toward the "care and comfort" of the patients. The cures were supplied principally by an apothecary from El Puerto de Santa María, Francisco Maldonado, who provided medicines in exchange for almost all of the hospital's budget (2,200 reales in 1605, 3,000 in 1606). Any remaining funds bought sugar, almonds, eggs, and chickens (the standard diet for the sick), almost always from Antonio Alfenio. In fact, however, 1,200 reales from the budget for 1603 were spent on rations for soldiers and sailors, recorded separately, so that receipts and expenditures were rarely in balance.

For this reason, charitable donations were essential if the hospital was to function. The monk was in charge of collecting them, and at each pay period he passed the hat among seamen and salaried rowers. ${ }^{91}$ His largest windfall usually came in July and added up to several thousand reales (more than 4,400 reales in 1607). In fact, these alms formed such an important component of the annual budget that the hospital often proceeded on advances made by the paymaster against future donations. ${ }^{92}$

88 ADM, AH, ramo 2-5, 25 January 1619.

89 Gracia Rivas, "Sanidad," 172.

$90 \quad$ Storrs, "Health, Sickness," 346.

91 Rodrigo Alfonso, "Hospital," 309-10.

92 AGs, CMC, 3 a Época, 397, 1436. 
Aside from this collective solidarity, individuals also stepped in to offer aid. When the quartermaster Mateo de León died indebted (in the last chapter we saw that his two female slaves were sold at auction), his friend and guarantor Miguel de Vilar, skipper of a Galley of Spain, was imprisoned. With the Crown demanding a payment of 300 ducados, the brothers Juan and Antón Agustínpilot and skilled seaman of the flagship, respectively—offered 1,0oo reales in cash in exchange for his freedom; the balance of the debt would be deducted from his back pay. It seems that Vilar and the Agustíns were cousins, ${ }^{93}$ but guarantors did not have to be family members. After several slaves escaped from a Galley of Denia in October 1619, a buenaboya offered himself as guarantor for part of the fine imposed on the three sailors arrested for failing in their guard duty. ${ }^{94}$

How could salaried rowers have enough money to donate to collections and even give financial support to their friends? Boatswains, cómitres, were key players here and formed one more link in the long chain of favors that was forged in the galleys. Beside maintaining discipline among the rowers, these officers were intermediaries when others sought workers for "extraordinary" duties. They knew which men were strongest or most trustworthy. Sometimes, they chose slaves to haul water or wood; at other times, they contracted freemen for day labor. In February 1602 Gian Andrea Doria asked the cómitre of the royal galley to find buenaboyas who might want to leave the galley for at least a month and earn some extra money for "digging my vineyard, for which I will give them my usual sum, but they must pledge to each other not to run away."95

Rowers could benefit from friendships not only with their cómitres but also with their captains. In October 1600 the auditor of the Galleys of Genoa brought suit against Captain Alessandro Mutio and other officers of the viceflagship Spinola for having freed a rower named Saba' without permission. Apparently, he was a poor man who "didn't have a cent," but it was known aboard that "several times Saba' had begged Alessandro to help him." Somehow, his pleas persuaded both Mutio and another "gentleman" of the galley to seek a way to ransom him. Finally, the skipper of a ship from Sestri Levante offered to mediate, with the result that without permission and for an unknown sum Saba' was released in Genoa. For several weeks, he was seen wandering unchained around the city, seeking passage to North Africa, while presumably living at the home of the man who had freed him. ${ }^{96}$ Such "galley friendships,"

93 AGs, GyM, 677, fol. 680.

94 ADM, AH, ramo 2-5, 22 October 1619.

95 ADP, scaffale 85, busta 23: Gian Andrea Doria to Pietro Serra, 7 February 16o2.

96 ADP, scaffale 82, busta 24: Cesare Massa to Gian Andrea Doria, 5 October 16 oo. 
as Doria called them, ${ }^{97}$ which could sometimes be close, arose from inevitable contacts aboard ship. Although we have little documentation of relationships between slaves and convicts, we have much more for ties between slaves and officers.

In 1592 Miguel de Zufre had to respond to the findings of the licenciate Alcázar after the Visit of 1591. A chief witness on his behalf was the captured slave Jerónimo Pérez, a mulatto whom the quartermaster had made his assistant; he was found to be living in sin with a woman from Cádiz..$^{98}$ In June 1590, when the corregidor of El Puerto de Santa María arrested Romanico, a cómitre in the Galleys of Spain, and charged him with sodomy, he found him to be a former slave whose officers had trusted him enough to elevate him from the rowers' benches. The corregidor offered to pay his assessed price of 300 reales if his shipmates would surrender him to be burned at the stake, but it seems that they managed to free him. ${ }^{99}$ If a slave could achieve the respected status of cómitre, or live as an ordinary citizen of Cádiz while helping officers of the fleet with their affairs, it is unsurprising that some might even be assigned to guard duty at night. In 1600 Cesare Massa complained of that after two prisoners had escaped from the galley Doria while only one sailor was on guard: "It is of little benefit to assign slaves, because they do not apply ... care and diligence." ${ }^{100}$ In the same year, the Count of Santa Gadea noted in a letter that when galleys of the Marquis of Santa Cruz were sent to Lisbon, men were so few that "they divert slaves to guard duty."101 Perhaps the most picturesque example of the trust placed in slaves took place in 1604. While Philip III was holding Cortes in Valencia, the Duke of Lerma "conspired with Don Carlo [Doria, the Duke of Tursi] to play a joke on the court that accompanied His Majesty. They decided to send a frigate loaded with sailors and slaves, all dressed as Moors, to disembark near Oliva and frighten all the wagons and servants who were marching toward Denia, and so put the whole Court to flight."102

If slaves could attain unheard-of positions of trust aboard, that was even more true of convicts, who sometimes enjoyed the same type of "social" promotion. In January 1599 Diego Sánchez de Marchena, after twenty-four years of service, asked the purser Martín de Durango for his freedom. He actually

97 ADP, scaffale 85, busta 23: Gian Andrea Doria to Diego Pimentel, 10 November 16o2.

98 AHN, Consejos, 4041.

99 ADM, Puerto de Santa María, 7, pieza 6o.

100 ADP, scaffale 82, busta 24: Cesare Massa to Gian Andrea Doria, 10 December 16oo.

101 AGs, GyM, 567, 163.

102 ADP, scaffale 82, busta 30: Gio Antonio Marini to Gian Andrea Doria, 24 January 1604; Cabrera de Cordoba, Relaciones, 207. 
did not wish to leave the galleys, where he had served as executioner, but after demonstrating for years that he was "good at his job," he hoped to earn a salary as a freeman and support his children. In 1600 the Council of War granted his request and gave him 50 escudos, ${ }^{103}$ proving that in the galleys a man could begin as a rower but could, over time and by gaining his officers' trust, forge a career in service to the monarchy.

A striking story is that of Rodrigo Moreno. In February and March 1607 he came to court to present documents to Aróztegui, the secretary, hoping to have them considered by the council. The first one was drawn up on behalf of all the convicts in the Galleys of Spain who had been sentenced to life or to several decades as rowers; they pleaded for their freedom on several grounds, but especially illness and old age. ${ }^{104}$ The second petition came from Gonzalo Solís, a former lieutenant and veteran of Flanders who had been rowing for nine years. With only one year left of his sentence, he asked to be freed because he was poor, wounded in the arms and legs, and above all dishonored by having ended in the galleys after more than twenty years' service in army regiments and the Casa de la Contratación (which administered trade with the Indies). ${ }^{105}$ But the most revealing petition of all those that Moreno presented to Aróztegui was his own. This "representative" of the convicts had once been a convict himself. It seems that after his four-year sentence in the Galleys of Spain he had accepted an offer to continue as a salaried rower, spending fifteen years in that capacity. When his grateful officers proposed making him a soldier, he then served three years in the ranks. But during his slow, difficult ascent, Moreno had never forgotten where he came from, and he helped other convicts whenever he could. This was his third approach to the court with appeals from his former shipmates and himself. Moreno had "given his youth" to service in the galleys and, like Diego Sánchez, did not wish to leave them, but he had not yet received his soldier's pay and was still owed many years of rations as a buenaboya. Nonetheless, the council did not offer him any redress. ${ }^{106}$

Loyal service could also lead a man to freedom fairly swiftly, though not without risk. When Lieutenant Solís submitted his petition to Moreno for the Council of War, he mentioned one of the most interesting periods of his irregular life, his second stretch as a rower. Years before, while rowing in the galleys of Federico Spínola, he had been unchained and armed so that he could fight in an engagement in the English Channel. Apparently, he had been captured

\footnotetext{
103 AGS, GyM, 577, 10-11.

104 AGs, GyM, 677 , fol. 36 .

105 AGs, GyM, 677, fol. 124.

106 Ags, GyM, 677, fol. 61 .
} 
by the Dutch, and had managed to escape and return to Castile, but once there had violated the terms of his banishment, which earned him a new sentence to the galleys. ${ }^{107}$ Such cases were more frequent than one would suppose; captain's general often promised liberty to rowers who showed genuine courage in combat. Luis de Torres, a convict serving a life sentence in the Galleys of Portugal, earned his pardon in that way. During an engagement in the Algarve, he was unchained and allowed to arm, then leapt onto the enemy vessel, receiving several wounds. On that basis, and after thirteen years of rowing, he was freed "so that others may be inspired on similar occasions," though he was banned from returning to Antequera, where he had committed his crimes. ${ }^{108}$

In the armies of the Hispanic Monarchy, professionalization of command structures supported the troops and added to their effectiveness in combat. The entire edifice rested on loyalty, which was created, preserved, and enhanced through rewards. According to Davide Maffi, in practice this meant that captains general based their authority in large measure on distributing favors and honors; these descended from the top of the pyramid to its base and, though usually small, could increase over time through promotions and other means. The ultimate goal was to renew continually the fealty of each fighting man toward his commander. ${ }^{109}$

Galley squadrons reproduced this system while adapting its benefits to the greater legal, social, and professional diversity of those who manned the ships, especially rowers. Rowers could not expect financial aid or a pension; nor could they, as officers often did, appropriate the salary of a nonexistent seaman. But they could hope for lighter duties, a ransom, a review of their sentences, or even a pardon. Men could be promoted from salaried rowers or cómitres to soldiers or pilots, depending on their skills. Though the galleys seemed divided into strict hierarchies of convicts, sailors, and officers, all more or less privileged, integrated, or marginalized, in fact each sector held the possibility of change (through service, money, or influence of friends), irrespective of a man's original position.

The galleys also reflected the structure and organization of Mediterranean societies on land, extending them but adapting them to their special circumstances. The reduced space on board made everyone share the same discomforts and eliminated the limits and barriers that existed elsewhere, making it possible to form relationships that would have been unheard of ashore. ${ }^{110}$ For example, a Flemish convict rowing in the Galleys of Genoa in 1599 was able to

\footnotetext{
107 AGs, GyM, 677, fol. 124.

108 AGs, GyM, 677, fol. 393 .

109 Maffi, Baluardo, 191, and En defensa del Imperio, 322-23.

110 Judde de Larivière, Naviguer, 47.
} 
speak in person with Nicholas Damant, chancellor of Brabant and president of the Council of Flanders, during the voyage that brought Queen Marguerite to Valencia; Damant later asked Gian Andrea Doria to grant the man's freedom. ${ }^{111}$ Galleys were among the few spaces that reflected the cultural and religious diversity of the Mediterranean, especially through their large complement of slaves. We wonder whether captains general used this circumstance as one more mechanism for protection, patronage, and the creation of loyalty.

\section{$3 \quad$ Religious Belief}

On August 14, 16oo, captain general García de Toledo sailed out along the Calabrian coast with six galleys. He had received several reports about the presence of three galliots from Bizerte, and since his flotilla had left on Assumption Eve, he expected the Virgin's help in capturing the enemy. His prayers were answered. At dawn on August 15, they spotted the Tunisian ships, which immediately took flight. Toledo, with his fellow captains, decided which galliot was the leader, and each skipper set off in pursuit of his assigned prey. The chase stretched into several hours, as often happened, and García de Toledo could not overtake his galliot until nightfall, when he faced an unexpectedly fierce adversary. The Tunisians' fire was so intense that it killed nine soldiers and sailors and wounded another thirty-two, but worst of all, three rowers were among the dead. Those losses produced such disorder in the benches that the galley lost speed, resulting in the Tunisians' escape.

Fortunately, two of the Neapolitan galleys had captured an enemy ship, which turned out to be the leader, seizing about one hundred slaves and freeing many captive Christians from their chains. ${ }^{112}$ García de Toledo, his pride wounded, tried to repair his reputation and justify his actions. He set the Christian captives free with great pomp in a public ceremony in Messina. Meanwhile, the other two captains, "men very close to him," fought to be recognized as the first to overhaul the prize, ${ }^{113}$ a condition for being awarded the "jewel," one's first pick of the captured slaves. Captain Pedro de Chaves insisted that he had been the first to touch the galliot's stern, destabilizing it enough to allow him to fire his guns and begin boarding; he himself had planted on the enemy deck a flag with an image of the Virgin, to whom he attributed his victory. ${ }^{114}$ His

\footnotetext{
111 ADP, scaffale 82, busta 21: Nicholas Damant to Gian Andrea Doria, 20 May 1599.

112 ADP, scaffale 82, busta 24: García de Toledo to Gian Andrea Doria, 16 August 1600.

113 ADP, scaffale 82, busta 24: Captain Bermúdez to Gian Andrea Doria, 18 August 1600.

114 ADP, scaffale 82, busta 24: Captain Chaves to Gian Andrea Doria, 18 August 1600.
} 
rival, Captain Bermúdez, could do little to counter that dramatic symbolism but insisted that his own galley, outstripping the others, had been the first to touch the enemy stern and draw level with the galliot's starboard side while letting off a volley of arquebus fire. That action had slowed the ship's way and allowed his colleague, who came from behind, to attack and board her. ${ }^{115}$

\subsection{Catholic Belief}

The tale of how the flagship from Bizerte was captured gives us some insight into how religious belief was lived and expressed aboard the galleys. First, we must stress the importance of worship of the Virgin Mary, which operated on two levels. When Pedro de Chaves raised his galley's Marian flag to mark his victory, we glimpse how that image could be employed for political and personal ends. In Chapter 1 we described how the people of Naples reacted in October 1618 when the Duke of Osuna raised the Virgin's standards over the ships in his fleet. He intended his order to manifest the oath he had taken "as to the article of the Conception of the Virgin ... showing myself truly and specially devoted to her."116 He thus presented himself publicly as a defender of the faith that was growing in weight and influence in Spanish politics, while at the same time he offended Neapolitan religious groups headed by Cardinal Caraffa. Those men were scandalized at how the crewmen of the fleet were obliged to swear an oath to the Virgin of the Immaculate Conception, while the black flags that flew from their masts bore both the image of Mary and the arms of the House of Girón. ${ }^{117}$

Osuna achieved the dual goal of renewing his ties to the discourse and political program of the monarchy (in fact, his family had made that pledge long before) and of consolidating his position vis-à-vis his rivals. This was not the only time he had used his leadership of the fleet toward those ends. Only a few months earlier, in August, he had attracted notice by delaying his ships' sailing until after the feast of the Blessed Ignatius of Loyola and donating a silver lamp in person to the Company of Jesus. ${ }^{118}$

While Pedro de Chaves's objectives in 1600 were more modest, they were not so different from Osuna's. Although we know nothing of Chaves's early years, he appears in May 1599 in Barcelona petitioning the Count of Lemos, just named viceroy of Naples, for the command of a new galley-his current one, the San Felipe, was old and almost useless. Further, he was competing in

\footnotetext{
115 ADP, scaffale 82, busta 24: Captain Bermúdez to Gian Andrea Doria, 18 August 1600.

116 Asv, Segretaria di Stato, Avvisi, 8, fols. 45or-451v.

117 Linde, Don Pedro Girón, 308-10. See Le Flem, “Arithmétique navale."

118 Asv, Segretaria di Stato, Avvisi, fols. 58r-65r.
} 
this request with another captain, a "young man" like himself, named Bermúdez. That presented a problem. Chaves had just arrived from Cartagena with his wife and children after having sold "everything he owned," so he needed the viceroy's patronage not only to advance in the service but also to establish a new social position for his family in Italy. ${ }^{119}$ Luckily, Lemos decided to favor the two captains equally (after all, his own situation was not so different), and he gave each of them command of a new galley. ${ }^{120}$ Against this background, it is easy to understand why, only a year later, these two captains showed such zeal in capturing a prize, probably the first one that presented itself since they had been favored by Lemos. Both men needed to prove their worth and position within the squadron, so Chaves did not hesitate to use every means at his command to outshine his rival. In linking his victory to the Virgin, he was aware of the influence of such a gesture; his own captains general had used the same resource in constructing their discourse and justifying their actions.

Chaves did not triumph, alas. After an inspection of the spur at each galley's prow, it was determined that Bermúdez's account was the more plausible one. ${ }^{121}$ But the squadron's captain general had used the same stratagem - the Virgin's protection-when his ships sailed out just before Assumption Day. The gesture was connected not only to political and symbolic goals but also to sailors' unceasing search for mediation and protection in the face of all the uncertainties and misfortunes of life at sea. ${ }^{122}$

Not by chance was the brotherhood of Our Lady of Miracles in El Puerto de Santa María made up of soldiers, sailors, aspiring officers, and captains of the Galleys of Spain. In southern Andalusia a devotion to that Virgin was linked to the discovery and evangelizing of America, highlighting the importance of sailing and sailors in the propagation of the faith. Her feast day in August was an occasion for crewmen to seek her succor with greater fervor during the season of campaigns. In 1615 they reached into their pay to donate a silver lamp costing almost 10,000 reales to her shrine, ${ }^{123}$ and early in the century they spent hundreds of reales in pledges to her. These sums were distributed to several foundations. The monastery of San Francisco received similar amounts-1,500 reales in 1605, in two payments on August 11 and 29, perhaps corresponding to the departure and return of an expedition to Oran. ${ }^{24}$ The principal beneficiary

119 Varachaud, Franceschi, and Zysberg, “Qui étaient les capitaines?"; Cabanous, Mer, 57-6o.

120 ADP, scaffale 82, busta 21: the Count of Lemos to Gian Andrea Doria, 15 May 1599. See Favarò, Gobernar, 77-82; Enciso Alonso-Muñumer, Nobleza, poder y mecenazgo, 222-23.

121 ADP, scaffale 82, busta 24: Gian Andrea Doria to García de Toledo, 18 August 1600.

122 Civale, Guerrieri, 118-27.

123 AGs, GyM, 846: “La cofradía de Nuestra Senora de los Milagros ...," 19 July 1619.

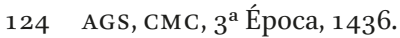


was the brotherhood of Our Lady of Charity and Piety - formed by the squadron itself in 1576 125 — which in 1614 alone took in more than 7,00o reales from alms collected among the crews. In those same years, there were smaller donations to the sacristan of Our Lady of Mercy in Barcelona and the monastery of San Diego in Cartagena. ${ }^{126}$ Clearly, many men in the squadron were actively seeking consolation and spiritual protection through donations and endowments, although the recipients rarely received the full amounts pledged.

The galleys' brotherhood could probably count on a fairly stable income; we can trace through its account books how captains made substantial loans to help individual crewmen, charging them to the brotherhood's funds. But many sailors' endowments and donations were hard to deposit. In 1607 the friars of the San Francisco monastery sued the financial officers because, over the years, galley crewmen who confessed and received the sacraments with them had run up a debt of almost 9,ooo reales. The friars asked that such alms not be debited to the mens' pay but be drawn on profits from mazamorra, the sale of superannuated slaves, or prize money, sources that, as we know, were problematic in themselves. ${ }^{127}$

The men's wives also took part. On days like August 5 , the Feast of the Virgin of the Snows (patroness of marital devotion), they gathered to pray "to God for the ministers of the Catholic King" and for their husbands, as the Marchioness of Santa Cruz and her ladies did during the Relief of Genoa in $1625 .{ }^{128}$ There were also moments when naval battles took place near the coast and people gathered to watch and pray. In 1618, during a battle "so fierce that it frightened many people who were watching from the Rock of Gibraltar ... the Holy Sacrament was displayed in all the churches" of the city "while prayers were said."129

The Marian calendar also reinforced this mediation, as the most auspicious dates for sailing and combat were chosen from it. We have already seen how García de Toledo did so in 1600 . It is surely no coincidence ${ }^{130}$ that all the captains general who facilitated the expulsion of the Moriscos from the kingdom of Valencia in 1609 began their embarkations on the eve and feast day of the Virgin of the Rosary, patroness of the Christian victory at Lepanto. ${ }^{131}$ The Marquis of Villafranca acknowledged in 1611 that the fleet sailing to occupy Larache

125 Marchena Giménez, "Vida y los hombres," 418-20.

126 AGS, CMC, 3 a Época, 1454.

127 AGs, GyM, 677, fol. 674 .

128 ASv, Segretaria di Stato, Avvisi, 11, fols. 227r-231v.

129 Asv, Segretaria di Stato, Spagna, 6oE, fols. 218-2o.

130 Lomas Cortés, Proceso de expulsión, 100-24.

131 Rivero Rodríguez, Batalla de Lepanto. 
the previous year had waited until November 20, the Feast of the Presentation of the Virgin, to ensure a "good outcome" for the expedition, and that as a result "Our Lady, on the eve of her feast day, granted him that fortune."132 Prayers uttered aboard the galleys had also begged for divine intervention. To ensure that "God would direct [the taking of Larache] as His own cause, so that His holy name may be praised there," Villafranca asked the chief purveyor, as an exceptional favor, to loan him the utensils for mass that had been in storage since the royal galley was disarmed in 1601 . Those fifteen pieces (which included a cross "with its crucified Christ and Calvary and two images on the sides, all of silver," a box for the sacred implements, chalice, paten, oil vessels, and bell of the same metal, a missal, and several lengths of velvet and linen for the altar and the chaplain's robes) ${ }^{133}$ would connect the crew spiritually with the just cause in which they were engaged. Each galley also contained its own holy objects, received on the day of its launching.

In his gloss on a narrative by Pere Joan Comes, Capmany i Monpalau explains how in Barcelona each galley, after being baptized with the name of a patron saint and blessed, would perform the ritual of "saying the good word," an auspicious prediction. At the launching of the Santa María in 1424 a sailor had cried, "May God preserve her to fight the Turks and the French!," to which all those present had responded, "Let it be so!"134 Later on, captains general could change a ship's dedicatee. Juan Riambau, quartermaster of the Barcelona shipyards, explained in 1599 that of recently launched galleys the San Pablo had become the Esperanza, the Santiago was renamed the Bazana, the San Telmo was now the Fama, the San Francisco the Fortaleza, the San Pedro the Quimera, the Santisima Trinidad the Ocasión, the San Juan the Ventura, the San Andrés the Victoria, and so on. Sometimes the change was meant to exalt the family of the armer, but new names most often referred to the cardinal or theological virtues, alluded to a successful mission, or announced a victory (or the hope of one). Works of humanism or Antiquity underlay this symbolic structure, in which the monarchy also participated. Riambau notes that the king had ordered every galley to bear on its stern a carved "wooden escutcheon with the name of Jesus at the center."135

If to all this we add the blessings and pious donations that the armadas received, we see that religious expressions, for various reasons, played a significant role in organizing campaigns and the ways in which sailors faced them

\footnotetext{
132 AGS, GyM, 742: the Marquis of Villafranca to Juan de Ciriza, 20 November 1610.

133 AGs, GyM, 741: Miguel de Oviedo to Philip III, 7 October 1610.

134 Capmany i Monpalau, Memorias históricas, 1:48-50.

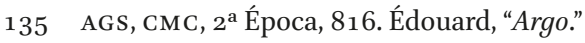


or justified them after the fact. But we should not confuse the special circumstances of such events with the everyday spiritual climate aboard the galleys or in port. As the friars of the monastery of La Encarnación in El Puerto de Santa María knew all too well, very little charity was forthcoming from officers or crew. In the whole period under study, they were paid only for a few masses in memory of the quartermaster Mateo de León. ${ }^{136}$

\subsection{Vice among the Crews}

The friars' quarrels with soldiers and sailors of the squadron went back to the earliest years of their presence in the town. In January 1574, not long after Augustinian friars had founded La Encarnación, they complained of their precarious situation to the Duke of Medinaceli. Shortly before, the duke had given them an old abandoned convent in the center of town; it was meant as the site for a new congregation that would elevate the lamentable spiritual life of residents along the river where the Galleys of Spain dropped anchor. But crewmen had not been received there with open arms. Homeowners in nearby streets complained to the corregidor that the presence of the new institution had the friars "lording it over" them, their wives, and their daughters. The squadron's people joined the outcry, claiming that the abandoned building had been used as a hospital for ailing seamen, a function that the monastery had abolished. But the friars told another tale of what had gone on inside the building, stating that the "hospital" was no more than an improvised brothel: "We will not refrain from telling how this church and house had been profaned and what abominations were committed here ... as is well known to all." The trade had been so attractive that owners of many houses rented them out "for twice their worth to the bad women and prostitutes who come when the galleys are in port, and because [their houses] are close to them people give more than they should, and they know that since there are men of religion here they should not accept such people."137

The problem was not easy to solve. In November 1619 the governor of El Puerto, in one more attempt to quell the defiance and licentiousness of soldiers from the galleys, followed one of them at night: "While visiting certain houses he entered that of a public woman, and as he was lying with her the governor visited that house as that of a bad woman, and he found the soldier in bed with her." The governor declared that "it was up to him to punish public disorder and sin," and when the soldier went for his sword the official "seized

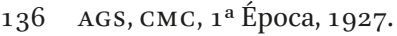

137 ADM, Puerto de Santa María, 6, pieza 38.
} 
him by the neck" and managed to take him to prison. But the next day several other soldiers went in search of the governor, "telling him that he was a swine and that if he interfered with the soldiers they would cut off his nose and ears." Threatened with being denounced to the city council, they retorted, "The council is garbage."

The episode proved once again that "the soldiers live impure lives, with great risk that there will be serious disturbances when their leaders cover and protect them; and because of their bad behavior the town is ruined and some residents are trying to leave it."138 But prostitution, like gambling, was an evil tolerated for the sake of the greater good (maintaining group cohesion and, to the extent possible, avoiding other threats to crew members' discipline and behavior). A report presented to Pius V in 1571 named prostitution as the greatest problem on board ship, because of its inherent scandalousness but, above all, because of two other issues derived from it. Since space was so limited on board, there was room for few loose women and "not all [the men] could have them," causing them to quarrel with each other; even worse, some in their frustration would "commit other abominable sins" that made "men too effeminate to fight." ${ }^{139}$ We know that this crime almost led a cómire to the stake in El Puerto in 159o. Gianclaudio Civale has studied the issue. ${ }^{140}$

Two further problems were associated with crewmen's deprivation (the "bad humors" they suffered) during long sea voyages. Gian Andrea Doria spoke of the first to several confidants in 16o1: "When women become pregnant (perhaps the air of this place favors it) and their husbands are a long time at sea, when on their return they sleep with them [the women] miscarry; it happens to them all and it has happened to me. ... We all told Don Carlos [Doria, the Duke of Tursi] that it would happen if he slept with his wife, but being young and in love he paid no attention,"141 and wishing "to sleep or spend the night with his wife while she was five months pregnant,"142 he paid her "so many favors" that he provoked an abortion. ${ }^{143}$ The second issue was jealousy. Pedro de Leiva, admiral of the Galleys of Sicily, claimed in 1598 that he had to make frequent stops at his crewmen's home ports because otherwise "there is no doubt that most of these people would desert me rather than lose either their wives or their daughters"144_ a situation that could lead to outbursts of violence, like

\footnotetext{
138 AGs, GyM, 858: "Sumario de lo que contiene la ynformaçión ynclusa fecha en el Puerto."

139 Asv, Miscelania Armadi, 2:116, fols. 139-41.

140 Civale, Guerrieri, 111-14.

141 ADP, scaffale 85, busta 22: Gian Andrea Doria to Jusepe de Acuña, 20 October 1601.

142 ADP, scaffale 85, busta 22: Gian Andrea Doria to Baltasar de Zúñiga, 5 October 1601.

143 ADP, scaffale 85, busta 22: Gian Andrea Doria to Diego Pimentel, 5 October 1601.

144 ADP, scaffale 7o, busta 24: Pedro de Leiva to the Duke of Maqueda, 2o October 1598.
} 
the one committed by Giovanni de Luca that we saw in Chapter 1. Permissiveness toward prostitution, then, could help to avoid certain problems on board, but it could also encourage them. We recall how in 1598 the musician Catalano attributed Grattapane's betrayal of him to a dispute over a woman; since convicts could rarely leave the ship, she must have boarded for one reason only.

Chaplains were not very effective in controlling these vices. In theory their job was to help tend the sick, administer the sacraments on board, and teach the soldiers good Christian habits - one more way of attaining victory. ${ }^{145} \mathrm{But}$ another duty was to act as a sort of sheriff to enforce "spiritual" punishments for the convicts. The one meted out to Antonio Boni serves as a perfect example. This twenty-two-year-old convict had been sentenced by the diocese of Savona to five years in the galleys for having practiced "many magical and superstitious experiments ... to gain the love of women ... and men respectively, and for having used ... intestines of animals ... with a certain powder, and with ample abuse of the holy mass, invocations of demons ... and divers diabolical and dangerous superstitions ... teaching them to other people and exhorting them to learn them." Under interrogation, he had even claimed that no harm could come to him "because God was his cousin and the Devil his grandfather." In the galleys, he had to receive "the crown of the Most Blessed Virgin Mary" every week, was put on bread and water on Fridays, and was obliged to confess at least on Christmas, Easter, Pentecost, and All Saints' Day. ${ }^{146}$

But as an accusation against the chief purveyor Miguel de Oviedo revealed in 1611, chaplains were far from modeling good Christian behavior for their crews. They were neither visiting sick convicts nor hearing deathbed confessions nor administering the sacraments. The problem was most acute during sea voyages, because many chaplains simply failed to report for duty when the galleys were leaving port. The senior chaplain of the Galleys of Spain, Hernando de Chaves, had called them to account many times; finally, in early 1611, exasperated with the situation, he had threatened excommunication for all those who did not fulfill their responsibilities, which included making daily visits to rowers to monitor the health of their souls and reciting the Hail Mary with them both in port and at sea.

It seems, however, that those efforts originated not with the senior chaplain but with an order from the Marquis of Villafranca to expel Diego de Cáceres from his chaplaincy. There were two grounds: Cáceres had not tried to save the souls of the seamen in his charge, and he had behaved improperly during the

145 Lavenia, Catecismo, 25-26.
146 AGs, Galeras, fol. 36 o. 
occupation of Larache a few months before. During that expedition, a man had died, Francisco Jordán, "a cooper from the galley San Pedro, a young man who had no home or residence but usually worked in the galleys." It seems that at death's door he had willed a sum of money meant for fifty masses for souls in Purgatory, but without specifying "where they should be said." Cáceres, who was present, decided to share out the bequest among the squadron's chaplains, "because they are poor and because it belonged to them, since as has been said he [Jordán] died in ... the land of Barbary." Villafranca viewed this as theft, especially since the chaplains were not doing their jobs. Hernando de Chaves, in defense of his chaplain, maintained that Villafranca simply wanted to benefit the main church of El Puerto de Santa María, and in revenge had not only eliminated Cáceres's position but had written to the collector of the archbishopric of Seville asking him to accept the bequest.

Chaves accused Villafranca of trying to provoke a jurisdictional conflict between Seville and the chaplaincy of the squadron. ${ }^{147}$ But it is curious that the captain general should try to excommunicate chaplains who did not attend to their duties. Behind that façade, the real clash of wills was that between the respective jurisdictions of the captain general and the senior chaplain, both trying to control a crucial aspect of the policy that supported men in the galleys. (We recall how in 1625 a suit against the chaplain of the Galleys of Sicily also involved possible fraud in certifying the death and testament of a convict.) In the last instance, it was a question of chaplains' loyalty. Captains general could react forcefully to anyone who challenged them. Villafranca sent several soldiers to break into Hernando de Chaves's house and rouse him from bed, and would have put him in prison but for the mediation of Martín de Quijano. Shortly afterward the Marquis wrote to the Council of War claiming that since Chaves did not go aboard any galleys himself, he was no witness to his chaplains' performance or lack of it, that the galleys needed someone more learned who would attend to the matters that daily "come up ... with these wicked people," and that it would be best to pension off this "broken-down, decrepit" priest and have him leave the squadron. He intended to name a new chaplain whom he could trust. ${ }^{148}$

\subsection{Captains General and the Inquisition}

Control of the office of senior chaplain was crucial because, at least during Hernando de Chaves's time, that priest also served as the Inquisition's commissioner aboard the galleys and in El Puerto de Santa María. ${ }^{149}$ It is significant

\footnotetext{
147 Ags, GyM: Miguel de Oviedo to Philip III.

148 AGs, GyM, 759: the Marquis of Villafranca to the Council of War, 18 November 1611.

149 AHN, Inquisición, libro 585, fol. 403r.
} 
that an official "in the galleys of His Majesty acts as the commissioner of the Holy Office," because those agents served as delegates in the Inquisitors' districts, reinforcing the notion of squadrons as territorial entities. Commissioners received accusations and took witnesses' testimony, ${ }^{150}$ we know from the instructions to Andrés de Alva, who held that post in the galleys in 1573, that he performed those functions, with one specification. The commissioner should attend to those "who sail in them [and] accuse others in the same galleys of blasphemy"; he should hear their cases but then inform the Inquisition tribunal in the port where the galleys were anchored. Therefore, those cases could fall under more than one tribunal. The Galleys of Spain, for instance, normally used the Castilian tribunals of Murcia and Seville. That was where testimonies would be corroborated and trials continued, following two principles. If, when the report, was received, the post of inquisitor of the sea was occupied, as happened in 1573, the tribunal had to respect his jurisdiction and ask permission to ratify testimonies from crew members. If the sin was not a grave one (for example, in a case of blasphemy), it should impose only "spiritual penances such as the fasts, pilgrimages, and prayers that you think fit, without arresting them, warning them that from now on they should abstain from saying such words, and with this you will order them to return to the galleys." 151

This passage refers to one of the commonest sins committed by Christian rowers aboard the galleys. Blasphemy or a mere accusation of it, like an accusation of conspiring to mutiny, could lead to the Inquisition's removing a convict from his bench and (if the victim were lucky) imposing a sentence to be served on land. Luis del Valle, a convict rowing on the Leiva, tried to bring this about when he was accused of blasphemy and reconciled by the Inquisition in Murcia in $1575 \cdot{ }^{152}$ Not content with that, he repeated his behavior in 1576 , when he appeared before the Seville tribunal. ${ }^{153}$ One year later, his blasphemies were again noted in Murcia, but the Supreme Council finally ruled that "from now on you will pay no attention to what he says and writes, and will tell the captains that whenever he blasphemes and speaks about religious matters he should be severely flogged."154 That was not the only such warning in 1577 . In December, all the tribunals were advised that the convict Juan de Alvarado, "who has done penance in other inquisitions," tried to "exempt himself from work, and to avoid his [duties] had the idea of speaking great heresies and ...

15 O Bethencourt, Inquisición, 81 .

$15^{1}$ AHN, Inquisición, libro 578 , fol. 157 r.

$15^{2}$ AHN, Inquisición, libro 578, fol. 343r.

153 AHN, Inquisición, libro 579, fol. 18 r.

154 AHN, Inquisición, libro 579, fol. 119 r. 
most bold blasphemies before the Inquisitions of Seville, Granada, and Murcia," so that in the future "you must pay no attention to anything this man says to you ... he must serve in the galleys without ever leaving them, and you must warn the captains that when he speaks any heresy or blasphemy he must be severely flogged." ${ }^{155}$ These stern words do not seem to have done much good because Alvarado continued to deploy his strategy, resulting in a new appeal to the Holy Office in Seville in 1578.156

Aside from these isolated cases, captains general most often informed the Inquisition when they had captured renegade Christians at sea. It seems that some of those men were able to leave the galleys after abjuring de vehementi (strongly suspected of heresy): Lucas Arregoçes in Murcia in 1576, 157 Niqueta Griego and Bartolomé Genovés reconciled in Seville in 1579 (a case in which the captain of the vice-flagship ended up in prison), ${ }^{158}$ and a Morisco and a Frenchman whom the Murcia tribunal had removed with other renegades from the Galleys of Spain in 1590. All served out their sentences in different monasteries. ${ }^{159}$

As a general rule, however, captains general did not often send men to Inquisition tribunals. Only three petitions by high officials were recorded in the last fifteen years of the sixteenth century, aside from the case of Guillermo de la Fuente, a gunner from the Marquesa, investigated in 1585 for suspicion of possible Jewish ancestry. ${ }^{160}$ Gian Andrea Doria inquired in 1583 about the merits of a case against three Turks who rowed in his galleys, ${ }^{161}$ and in 1588 Carlo Centurione sent two men to the Inquisition in Murcia. ${ }^{162}$ And in 1591 the Count of Santa Gadea wrote to the Jesuit provincial requesting a priest who could convert several English convicts "who with a true heart, not a false one, wish to join our Catholic faith." Santa Gadea obviously had a personal stake in the outcome. ${ }^{163}$

Pedro de León described how Jesuit priests in Seville succeeded in their spiritual and physical care of rowers from the Galleys of Spain:

Aside from the many confessions ... that we heard from convicts, all of them [were] moved to confess and take communion in a body among much joyful noise from minstrels ... we have seen the great fruits gained

\footnotetext{
155 AHN, Inquisición, libro 579, fol. $118 \mathrm{r}$.

156 AHN, Inquisición, libro 579, fol. $168 \mathrm{v}$.

157 AHN, Inquisición, libro 578, fol. 374V.

$15^{8}$ AHN, Inquisición, libro 579, fols. 228, 232, 248.

159 AHN, Inquisición, libro 581 , fol. $309 \mathrm{v}$.

16o AHN, Inquisición, libro 580, fol. 319v.

161 AHN, Inquisición, libro 580, fol. $216 \mathrm{v}$.

162 AHN, Inquisición, libro 581, fol. $217 \mathrm{~V}$.

163 AHN, Inquisición, libro 582 , fol. 2 r.
} 
by them all, both soldiers and convicts. ... There were some conversions of convict Moors and Turks, who have learned the catechism and converted. In my time [there were] six Moors and Turks in our house, and to baptize them we took them in rich clothing to the principal Church in procession, with musicians and trumpet players and a large following ... [and] we returned to the galleys with the same following, where they acclaimed us with volleys and music. ... Once there, when all was calm, I would preach to them ... and the Moors and Turks who were there would be confounded and sometimes others would convert, from seeing how their companions were celebrated and how, after having been baptized, they lived as good Christians. ${ }^{164}$

No doubt spurred by Santa Gadea, the Jesuits increased their visits. In 1591 and for the rest of the decade permission was given for several campaigns of support and conversion, directed particularly from the recently founded English College (Colegio de los Ingleses) in Seville toward English convicts. Their main purpose was to obtain confession and penitence from all those men "of the sect of Luther and Calvin" who, because they were in the galleys, could not attend the Holy Office in person; the fathers would ratify their testimonies and request their release from the rowers' benches so that they could appear before the tribunal of Seville. There, sincere converts could be reconciled "without [wearing] the habit or having their goods confiscated, being assigned some spiritual penances," and the others absolved "ad cautelam [with caution] ... without reconciliation," under orders to be "instructed in the faith" and returned to the galleys. ${ }^{165}$

This solution did not wholly satisfy the captains general, however. In 1598 a correction was made, and the Jesuit Richard Walpole and the Supreme Council

164 "Allende de las muchas confesiones ... que les hacíamos a los forzados, moviéndose todos a confesar y haciendo comuniones generales con mucha fiesta de ministriles, ... se ha visto el mucho fruto que se ha hecho en todos, así en los soldados como en los forzados ... . Resultaron algunas conversiones de moros forzados y turcos, los cuales se han catequizado y convertido. En mi tiempo, seis moros y turcos en nuestra casa, y después, para bautizarlos, los hemos llevado muy bien aderezados de vestidos ricos a la Iglesia mayor en procesión, con menestrales y trompetas y mucho acompañamiento, ... [y] volviamos a las galeras con el mismo acompañamiento, adonde nos recibían con salvas de tiros y música ... . Llegados allá y sosegados les hacía plática, ... y los moros y turcos que allá estaban se confundían y algunas veces se convertían otros, así por ver las fiestas que les hacían a sus compañeros como por ver que después de bautizados vivían como buenos cristianos." León, Grandeza, 57-58.

165 AHN, Inquisición, libro 583, fol. 257v. 
were told that men had to be absolved or reconciled "without removing them from the galleys, finding a way to instruct them on board as well as possible."166 Though each captain general could decide for himself, those visits by Jesuits brought gifts of food and medical care that saved the squadron part of the limited annual budget for its hospital; in the end, however, any outside presence was problematic. As the contractors of the Galleys of Naples declared in 1587, the arrival of persons "to bring inquisitions into the galleys" was troublesome because they "not only inquire but also instigate."167 Gian Andrea Doria himself hated to have to receive such visitors politely, "for you know with what intent these men usually come here."168

The Marquis of Santa Cruz would have agreed. In 1563, after he had let a group of convicts recover in the Jesuit hospital in Seville, Father Sancho López denounced several Dutchmen among them to the Inquisition as Lutherans. Unfortunately, their trial did not focus on these rowers' actual religious practices, but tried to identify their Lutheran contacts in Flanders. ${ }^{169}$ For Santa Cruz, in any event, the result was the same: he lost several rowers to the Inquisition, to the detriment of his galleys' performance.

Not all officers saw the Jesuit presence aboard the galleys as positive. Martín de Quijano, for one, mocked them in 1594 in a letter to his brother-in-law, the purser Francisco de Aduna; although the letter has not survived, we can surmise its tenor from Aduna's reply:

Your sister and I have had a very good time reading it, and it pleased us greatly to learn of the special incident of the Jesuit fathers' visit ... . I would have shown it to the Marquis to give him a good laugh, and plan to do so when I have the chance, not ... just once, twice, or thrice but three hundred times.... You must have very good shoulders to have borne two little candles, and not the holy kind either. ... Now as a penance you will have to have the sweet name of JHs [both 'Jesus Christ' and 'the Society of Jesus'] always in your mouth, four holy beads on your rosary, and a few theological arguments in your head. ${ }^{170}$

166 AHN, Inquisición, libro 583, fol. $262 \mathrm{v}$.

167 ADP, scaffale 70 , busta 25 , interno 5 .

168 ADP, scaffale 85, busta 34: Gian Andrea Doria to Regent Castelet, 9 September 1605.

169 AHN, Inquisición, 2075, expediente 48.

170 " $\mathrm{N}]$ os ha dado boníssimo rato a su hermana de Vuestra Merced y a mí el leerla, y es tanto el gusto que nos dio el saver el particular subçesso del viaje de los padres de la Compañía ... . La hubiera mostrado al marqués para que se riera un rato, como lo pienso hazer en teniendo lugar, y no ... una vez, ni dos, ni tres, sino trezientas ... . Muy buenos ombros tiene Vuestra Merced, que sufría dos candelillas y no benditas ... . Bien podrá agora en 
If the galleys had had little contact with the Inquisition up to that point, beginning in the early seventeenth century they had even less. There was one petition from Juan de Grimaldo in 160o, ${ }^{171}$ and several rowers were handed over to the Murcia tribunal in $1603,{ }^{172}$ but after that officers of the galleys scarcely communicated with the Holy Office again. Perhaps, as the number of galleys in the squadron shrank and fewer men were needed, Inquisition cases fell in proportion; if thirty ships had generated few cases, a mere ten ships would present hardly any. But the general impression is that captains general showed little interest in controlling their rowers' Christian orthodoxy. Not only did the Inquisition's presence in the galleys impinge on their absolute authority, but removing rowers from the benches interfered with the squadron's performance. It also set a bad example, in that men could assume that an Inquisition trial might free them from rowing for a spell. (The Holy Office tried repeatedly to combat that type of excuse.) And since crewmen were condemned to the galleys already, the Inquisition was not really necessary. When in 1615 Emmanuel Filibert of Savoy was appointed the new captain general of the sea and (on his request to Philip III) the Inquisition of the Sea was reestablished, we understand that he was simply exercising a prerogative and not responding to an actual need.

A separate question is whether he exercised the privilege not in pursuit of greater Christian orthodoxy on board but for a different end. Rafael Benítez Sánchez-Blanco and I have explained how, in the years when the Galleys of Spain had their own inquisitor, their tribunal showed little interest in punishing renegades and Moriscos for practicing Islam. It cared much more about fighting for broader jurisdiction, which would allow it to conclude trials and pronounce sentences without appealing to other tribunals. ${ }^{173}$ It is tempting to speculate that behind that attitude lay an effort to remove the squadron from the influence of the few tribunals that still had the power to keep galleys from sailing and arrest their crewmen - because their jurisdiction was of a different order, and they were not subject to captains general. If the captain general of the sea had full control over an inquisitor of the sea, he could seem to respect the authority of the Holy Office while still keeping his rowers on board; that allowed him greater freedom of movement while making his jurisdiction even stronger.

penintençia contentarse con llevar siempre en la boca el dulçe nombre de JHs, quatro quentas benditas en el rosario y algunos puntos de theología en la caveça." AGs, Galeras, 216, fols. 637-39.

171 AHN, Inquisición, libro 584 , fol. $17 \mathrm{~V}$.

172 AHN, Inquisición, libro 584, fol. 298v.

173 Lomas Cortés and Benítez Sánchez-Blanco, "Seconde Inquisition." 
During those years the inquisitor of the sea, Martín de Vivanco, chose to open only a few cases in which rowers volunteered to confess their sins, but he ignored any accusations they made against their shipmates. His prudence shows how thoroughly Emmanuel Filibert of Savoy controlled the institution; he and his officers also ignored any heterodoxy among their Christian rowers so long as a galley's order, discipline, and seamanship were unaffected. A Valencian Morisco named Pedro Roget, alias Hamete, was serving a life sentence but made every effort to live in his galley as a good Muslim. He performed his ablutions like a "Moor," ate meat on Fridays and other Christian fast days, boycotted masses by chaplains and sermons by preachers, taught lessons on Islam from books he had on board, contradicted his cómitre, and argued about religion with Old Christian convicts - he was thought of as an actual faqih, an expert in the faith. He enjoyed great religious freedom, having been sentenced in 1606 and having served under three different captains general by that time. Such men were a problem only for chaplains, who tried in vain to tame them, but chaplains, too, had to please their superiors in the end.

If Moriscos' practices were tolerated, even more were those of North African slaves. Roget spoke in his confession about one aboard the San Francisco who also taught Islam and was taken for a faqih. As Vivanco complained when he demanded wider jurisdiction, after the expulsion of the Moriscos the Hispanic Monarchy still contained a space in which Muslims could exercise freedom of conscience, performing their rites as circumstances allowed, displaying their loyalty to Islam, and actively resisting their chaplains and inquisitors. But that resistance did not undermine the efficiency of the squadrons or challenge captains general and their military objectives; they reflected a more quotidian sort of conflict, like the ones that had arisen in many territories of the monarchy before the expulsion of $160 \mathrm{og}$. In this sense as well, galley squadrons reproduced elements of the society that surrounded them. The same dynamic had played out among nobles in Aragon and Valencia who, in exchange for loyalty and cooperation from their Morisco vassals, declined to hold them to strict Christian orthodoxy on their own lands.

The same could be said of chaplains, who were poorly paid and often uneducated; like parish priests of churches in former Muslim territory, they found their ministry very difficult and often shirked their duties. ${ }^{174}$ In the galleys, the Inquisition scarcely functioned, and chaplains lived alongside many North African Muslims. It is reasonable to conclude that religious permissiveness was one more way of building consensus aboard the galleys. This occurred in spite

174 Benítez Sánchez-Blanco, Heroicas decisiones, 314-25. 
of the weight given to expressions of Catholic religiosity, both the kind that many Christian crewmen lived daily, and the more political and symbolic variety deployed by officers who were experts at using religious displays to advance their careers.

The minimal interest that captains general showed in their men's spiritual lives forged one more link in a long chain of favors and contributed to a policy of cohesion among the various collectives that made up a galley's crew. Captains, at the tip of the pyramid, had to find a balance between punishing men and satisfying their demands, especially those of the rowers, in the context of the squadron's needs and while interacting with decisions by other tribunals. Although men might occasionally escape, this strategy (sometimes using unorthodox means) managed to avert serious mutinies that could lead galleys into the hands of their enemies. In practice, governance aboard the galleys often differed profoundly from the grandiloquent reports issued by their leaders and the avowed principles of a crusade. 